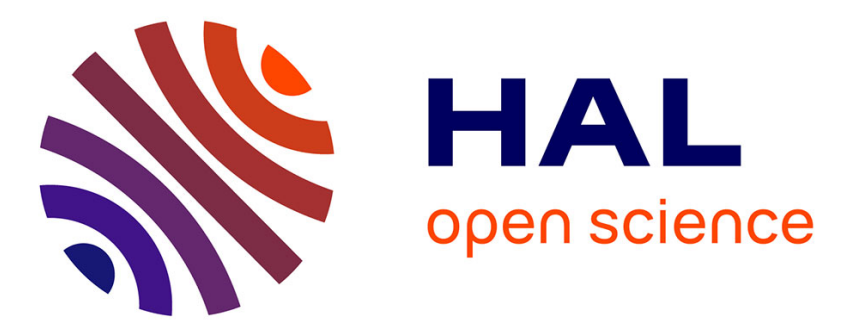

\title{
Dating groundwater with dissolved silica and CFC concentrations in crystalline aquifers
}

\author{
Jean Marçais, Alexandre Gauvain, Thierry Labasque, Benjamin W Abbott, \\ Gilles Pinay, Luc Aquilina, Francois Chabaux, Daniel Viville, Jean-Raynald \\ de Dreuzy
}

\section{To cite this version:}

Jean Marçais, Alexandre Gauvain, Thierry Labasque, Benjamin W Abbott, Gilles Pinay, et al.. Dating groundwater with dissolved silica and CFC concentrations in crystalline aquifers. Science of the Total Environment, 2018, 636, pp.260-272. 10.1016/j.scitotenv.2018.04.196 . insu-01779877

\section{HAL Id: insu-01779877 https://hal-insu.archives-ouvertes.fr/insu-01779877}

Submitted on 27 Apr 2018

HAL is a multi-disciplinary open access archive for the deposit and dissemination of scientific research documents, whether they are published or not. The documents may come from teaching and research institutions in France or abroad, or from public or private research centers.
L'archive ouverte pluridisciplinaire HAL, est destinée au dépôt et à la diffusion de documents scientifiques de niveau recherche, publiés ou non, émanant des établissements d'enseignement et de recherche français ou étrangers, des laboratoires publics ou privés. 
1 Dating groundwater with dissolved silica and CFC concentrations in crystalline

aquifers

${ }^{2}$ OSUR, Géosciences Rennes, CNRS, Université de Rennes 1, 35042 Rennes Cedex, France

${ }^{1}$ Agroparistech, 75005 Paris, France

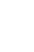

${ }^{3}$ Brigham Young University, Provo, UT, United States

${ }^{4}$ RiverLy-Irstea, Lyon, 5 rue de la Doua, 69616 Villeurbanne cedex, France

${ }^{5}$ Laboratoire d'Hydrologie et de Géochimie de Strasbourg (LHyGeS), CNRS, Université de Strasbourg, 67084 Strasbourg Cedex, France

\begin{abstract}
Estimating intermediate water residence times (a few years to a century) in shallow aquifers is critical to quantifying groundwater vulnerability to nutrient loading and estimating realistic recovery timelines. While intermediate groundwater residence times are currently determined with atmospheric tracers such as chlorofluorocarbons (CFCs), these analyses are costly and would benefit from other tracer approaches to compensate for the decreasing resolution of CFC methods in the 5-20 years range. In this context, we developed a framework to assess the capacity of dissolved silica (DSi) to inform residence times in shallow aquifers. We calibrated silicate weathering rates with CFCs from multiple wells in five crystalline aquifers in Brittany and in the Vosges Mountains (France). DSi and CFCs were complementary in determining apparent weathering reactions and residence time distributions (RTDs) in shallow aquifers.
\end{abstract}

\footnotetext{
${ }^{\dagger}$ Corresponding author: jean.marcais@univ-rennes1.fr
} 
Silicate weathering rates were surprisingly similar among Brittany aquifers, varying from 0.20 to $0.23 \mathrm{mg} \mathrm{L}^{-1} \mathrm{yr}^{-1}$ with a coefficient of variation of $7 \%$, except for the aquifer where significant groundwater abstraction occurred, where we observed a weathering rate of 0.31 $\mathrm{mg} \mathrm{L}^{-1} \mathrm{yr}^{-1}$. The silicate weathering rate was lower for the aquifer in the Vosges Mountains (0.12 $\left.\mathrm{mg} \mathrm{L}^{-1} \mathrm{yr}^{-1}\right)$, potentially due to differences in climate and anthropogenic solute loading. Overall, these optimized silicate weathering rates are consistent with previously published studies with similar apparent ages range. The consistency in silicate weathering rates suggests that DSi could be a robust and cheap proxy of mean residence times for recent groundwater (5-100 years) at the regional scale. This methodology could allow quantification of seasonal groundwater contributions to streams, estimation of residence times in the unsaturated zone and improve assessment of aquifer vulnerability to anthropogenic pollution.

Keywords: silicate weathering rates; Groundwater residence time; Groundwater age; Lumped Parameter Model; Atmospheric anthropogenic tracers (CFCs); Shallow aquifer.

\section{Introduction}

Human activity has fundamentally altered global nutrient cycles (Galloway et al., 2008), polluting aquatic ecosystems and threatening human health and water security (Spalding and Exner, 1993). It is widely held that anthropogenic loading of nitrogen has exceeded planetary capacities, representing one of the most pressing environmental issues (Rockstrom et al., 2009; Steffen et al., 2015). International, national, and regional initiatives have been undertaken in the past several decades to reduce nitrogen loading, though assessment of efficacy is difficult in complex natural systems with unknown and overlapping memory effects (Jarvie, 2013; Jenny et al., 2016; Meter and Basu, 2017; Wilcock et al., 2013). Estimating the recovery time of surface and groundwater ecosystems following nitrogen pollution is key to quantifying effectiveness of changes in agricultural practices, 
mitigation methods, and developing realistic timelines for meeting regulatory goals (Abbott et al., 2018; Bouraoui and Grizzetti, 2011; Jasechko et al., 2017). Recovery time depends largely on water and solute residence time in the surface and subsurface components of the catchment. The majority of catchment transit time occurs in the subsurface, where water can spend months to years in the soil or unsaturated zone (Meter et al., 2016; Sebilo et al., 2013), and decades to centuries in near-surface aquifers (Bohlke and Denver, 1995; Kolbe et al., 2016; Singleton et al., 2007; Visser et al., 2013). Because no single tracer can determine the distribution of groundwater ages across these timescales, multi tracer approaches are necessary for reliable groundwater dating (Abbott et al., 2016).

Several tracers are well suited to determine residence times for timescales relevant to nutrient pollution, including ${ }^{3} \mathrm{H} /{ }^{3} \mathrm{He}$ and chlorofluorocarbons (CFCs), because the atmospheric concentration of these gases were altered by human activity coincident with the great acceleration of nutrient loading in the mid-1900s (Aquilina et al., 2012b; Cook and Herczeg, 2000; Labasque et al., 2014; Steffen et al., 2015; Visser et al., 2014). However, CFC methods now lack resolution in the 5-20 years range because their atmospheric concentrations peaked around 1998 following their prohibition by the Kyoto Protocol (Figure 1). This reversal of atmospheric trends means any measured concentration between 1995 and 2018 corresponds to two dates. Additionally, 3H/3He and CFC samples are relatively difficult to collect and costly to analyze, limiting their use to infer residence times of groundwater in remote environments and much of the developing world. Therefore, there is great interest in developing new tracers for inferring mean residence time of young groundwater (Morgenstern et al., 2010; Peters et al., 2014; Tesoriero et al., 2005). 
68

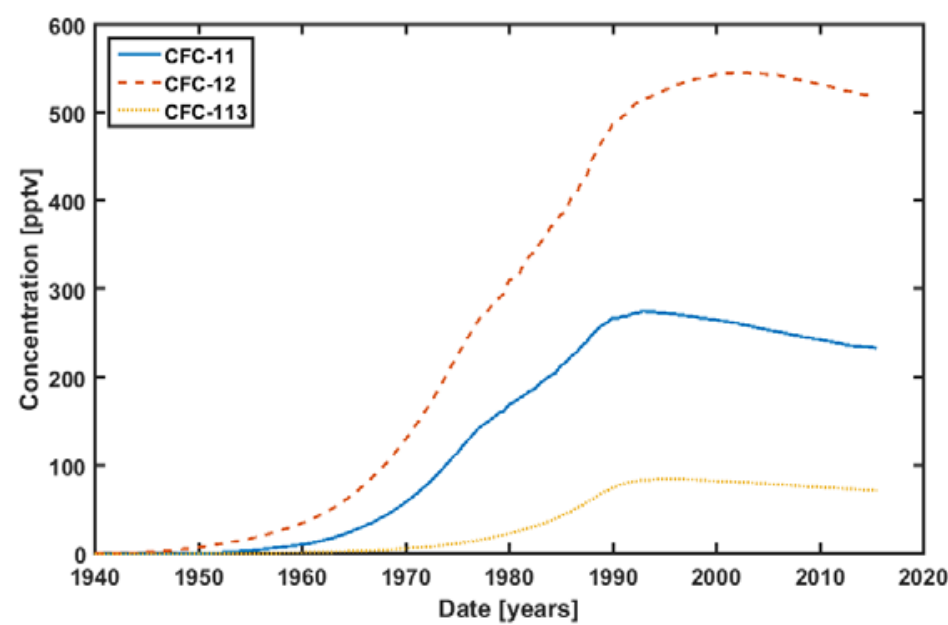

Figure 1: Atmospheric time series of CFC concentrations [pptv] since 1940. The lack of variations since the 2000s limits their resolution in the last 20 years. Adapted from (Cook and Herczeg, 2000).

One promising family of potential groundwater tracers is natural weathering products such as $\mathrm{Ca}^{2+}, \mathrm{Na}^{+}$, and dissolved silica (DSi) (Abbott et al., 2016). DSi has been found to be correlated with apparent age in several site-specific studies (Bohlke and Denver, 1995; Burns et al., 2003; Clune and Denver, 2012; Denver et al., 2010; Edmunds and Smedley, 2000; Kenoyer and Bowser, 1992; Kim, 2002; Lindsey et al., 2003; Morgenstern et al., 2015; Morgenstern et al., 2010; Peters et al., 2014; Rademacher et al., 2001; Stewart et al., 2007; Tesoriero et al., 2005). However, variability of weathering rates has not been precisely investigated and DSi has rarely been considered a robust tracer of groundwater age, though it has been used as a relative indicator of residence time (Beyer et al., 2016; Edmunds and Smedley, 2000). Two specific challenges to using DSi as a widespread proxy of mean residence times are: 1 . DSi lacks a time-based modeling framework and 2. it is unknown if silicate weathering rates are stable enough at geologic formation to regional scales to practically exploit DSi concentration.

In this context, we developed a new approach using groundwater DSi to determine residence time distributions (RTDs) by calibrating apparent silicate weathering rates with 
86

atmospheric groundwater age tracers (CFCs). We were motivated by the following questions: 1. Over what timescales can DSi be used as a tracer of groundwater age? 2. How variable is the rate of silicate weathering among shallow aquifers, i.e. a few tens of meters deep, with different lithology? We hypothesized that a simple zero-order kinetic reaction could simulate weathering rate in shallow aquifers, because hydrolysis would remain transport-limited to thermodynamically-limited on decadal timescales (detailed in section 2.1). Conversely, a time-variant weathering rate (i.e. a first order kinetic reaction) would be necessary to account for mineral equilibrium limitation in aquifers with longer residence times and a broader range of residence times (Appelo and Postma, 1994; Maher, 2010). We tested these hypotheses by modeling residence time distributions (RTDs) and weathering dynamics in 5 shallow crystalline aquifers with contrasting lithology in Brittany and the Vosges Mountains, France. We used conventional groundwater chemistry and dissolved CFCs from agricultural and domestic wells to calibrate chemodynamic models for each catchment, using an inverse Gaussian lumped parameter model to simulate RTDs. We compared our approach with previous methods and explored potential applications for regional issues of groundwater quality.

\section{Approach, catchment description, and geochemical data}

\subsection{Silicate weathering and DSi concentration}

Natural weathering products like DSi are cheap to measure and potentially contain additional information on residence time distribution compared to atmospheric tracers. Indeed they are sensitive to the overall residence time in both the unsaturated and saturated zones

(Figure 2), whereas atmospheric tracers are only sensitive to the residence time in the saturated zone (Cook and Herczeg, 2000). 
(a)

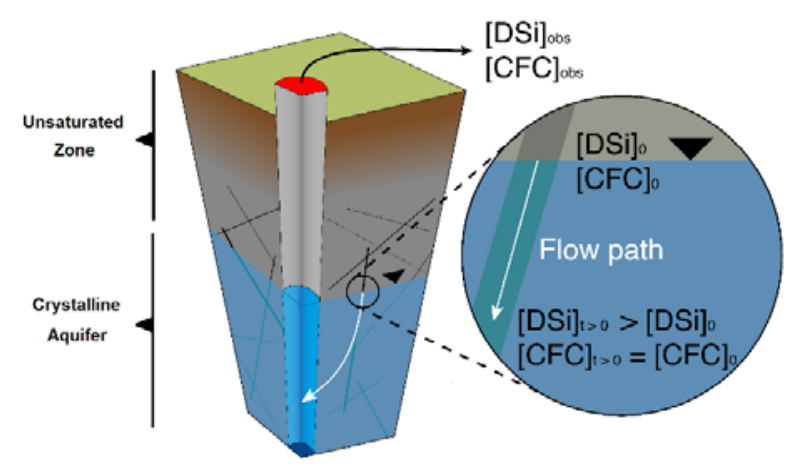

(b)

(c)
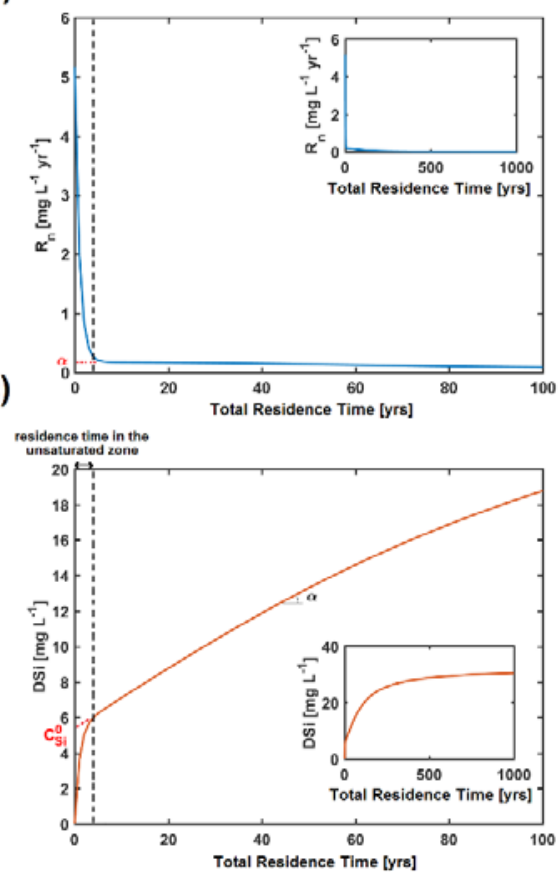

Figure 2: Weathering dynamics justifying our hypothesis of a zero-order kinetic reaction for the weathering of silicate minerals in shallow crystalline aquifers. On the time scales considered (5-50 years),

112 the weathering rate $\alpha$ can be considered constant due to transport-limited and thermodynamically-limited conditions (Maher, 2010). (a) Conceptual scheme illustrating the evolution of a groundwater flow path from the unsaturated zone into the shallow aquifer. (b) Corresponding weathering rate evolution on two different timescales. (c) Resulting DSi groundwater concentration evolution along a groundwater flow path.

Weathering is a rate-limited, non-equilibrium reaction consisting of physical, chemical, and biological processes that occur when mineral surfaces (e.g. bedrock) are exposed to water

118 flow (Anderson et al., 2002). Weathering occurs in virtually all terrestrial environments 119 including soils, sediments, and subsurface aquifers, and depends partly on the time that 120 groundwater has spent in contact with the rock (Maher, 2011). Silicate weathering is the 121 predominant weathering process because silicate minerals constitute more than $90 \%$ of the earth’s crust (White, 2008). As water moves through porous or fractured silicate substrate, it dissolves some silica 124 by hydrolysis (Maher, 2010). When surface water enters the subsurface, the initial rate of 
125 silica hydrolysis is determined solely by the contact area between water and rock (surface-

126 limited weathering). As water percolates deeper, DSi concentration increases at the rock-

127 water interface, slowing hydrolysis unless diffusive and advective mixing remove weathering

128 products from the interface (transport-limited weathering). Finally, as DSi concentration in

129 the whole water mass approaches saturation, second-order equilibrium reactions control

130 hydrolysis through precipitation of secondary phases (thermodynamically-limited weathering)

131 (Ackerer et al., 2018; Lucas et al., 2017; Maher, 2010). Consequently, hydrologic processes directly mediate weathering rate, because the speed and routing of water flow control the transport of solute and the cumulative mineral surface encountered by a volume of water.

Differences in weathering rates along and among flow lines can create spatial variations in DSi concentrations, depending on multiscale dispersive and mixing transport processes

136 (Gelhar and Axness, 1983). While the signature of detailed water-rock interactions is progressively erased by mixing processes, the homogenized concentration is more representative of mean weathering rate. Bulk transport models, including lumped parameter models, have been developed to analyze the distribution of residence times making up a mean

140 value on the basis of realistic transport conditions (Green et al., 2014; Haggerty and Gorelick, 1995; Maloszewski and Zuber, 1996). Because these models simulate recharge conditions and transfer processes through time, they can integrate both atmospheric and lithologic tracers, providing a flexible framework for inferring transport and weathering information from

144 multiple proxies of fundamental physical and chemical processes (Abbott et al., 2016; 145 Marçais et al., 2015). Specifically, lumped parameter models overcome practical limitations 146 in inferring weathering rates and determining residence times (e.g. determining the mixing 147 that led to observed CFC concentrations), by explicitly accounting for vertical sample 148 integration in wells and the diversity of flow paths contributing to that point (Maher and 149 Druhan, 2014; Marçais et al., 2015) 
150

151

152

153

154

155

156

157

158

159

160

161

162

163

164

165

166

167

168

169

170

171

\subsection{Catchment description}

We assessed the suitability of DSi as a groundwater age tracer with data from five catchments. Four of the five study catchments (Figure 3) are located in Brittany, France, where the climate is oceanic and average precipitation ranges from $900 \mathrm{~mm} \mathrm{yr}^{-1}$ in Plœmeur and Guidel catchments to $960 \mathrm{~mm} \mathrm{yr}^{-1}$ in Pleine Fougères and Saint Brice catchments (Jiménez-Martínez et al., 2013; Thomas et al., 2016a; Touchard, 1999). Land use in all these catchments is dominated by agriculture (i.e. $70-90 \%$ of arable land used for row crops) and in one of them, the aquifer is intensively pumped for municipal water supply (Plœmeur, hereafter the pumped catchment; pumping rate $=110 \mathrm{~m}^{3} \mathrm{hr}^{-1}$ ). The Pleine Fougères, Saint Brice and Guidel catchments are designated hereafter as agricultural catchments 1, 2, and 3, respectively. The fifth catchment is located in the Vosges Mountain (Strengbach, hereafter the mountainous catchment), in a forested region with elevation ranging from 880 to $1150 \mathrm{~m}$, an oceanic mountainous climate, and average annual precipitation of $1400 \mathrm{~mm} \mathrm{yr}^{-1}$ (Pierret et al., 2014; Viville et al., 2012). Though all 5 catchments are underlain by crystalline bedrock

(Figure 3), they differ in underlying lithology (granite or schist) and catchment size (from 0.8 to $35 \mathrm{~km}^{2}$; Table 1). They all have slightly acidic groundwater with $\mathrm{pH}$ between 5 and 7 (Table 1). Groundwater temperature is more variable among the catchments, ranging from $8^{\circ} \mathrm{C}$ in the high-elevation mountainous catchment to $\sim 13^{\circ} \mathrm{C}$ in the lowland Brittany catchments. The pumped catchment displays the strongest spatial variability of groundwater temperature, varying between 12 and $17^{\circ} \mathrm{C}$ due to the pumping activity (Table 1). Detailed site information is provided in the supplementary information and the references are listed in

\section{Table 1.}




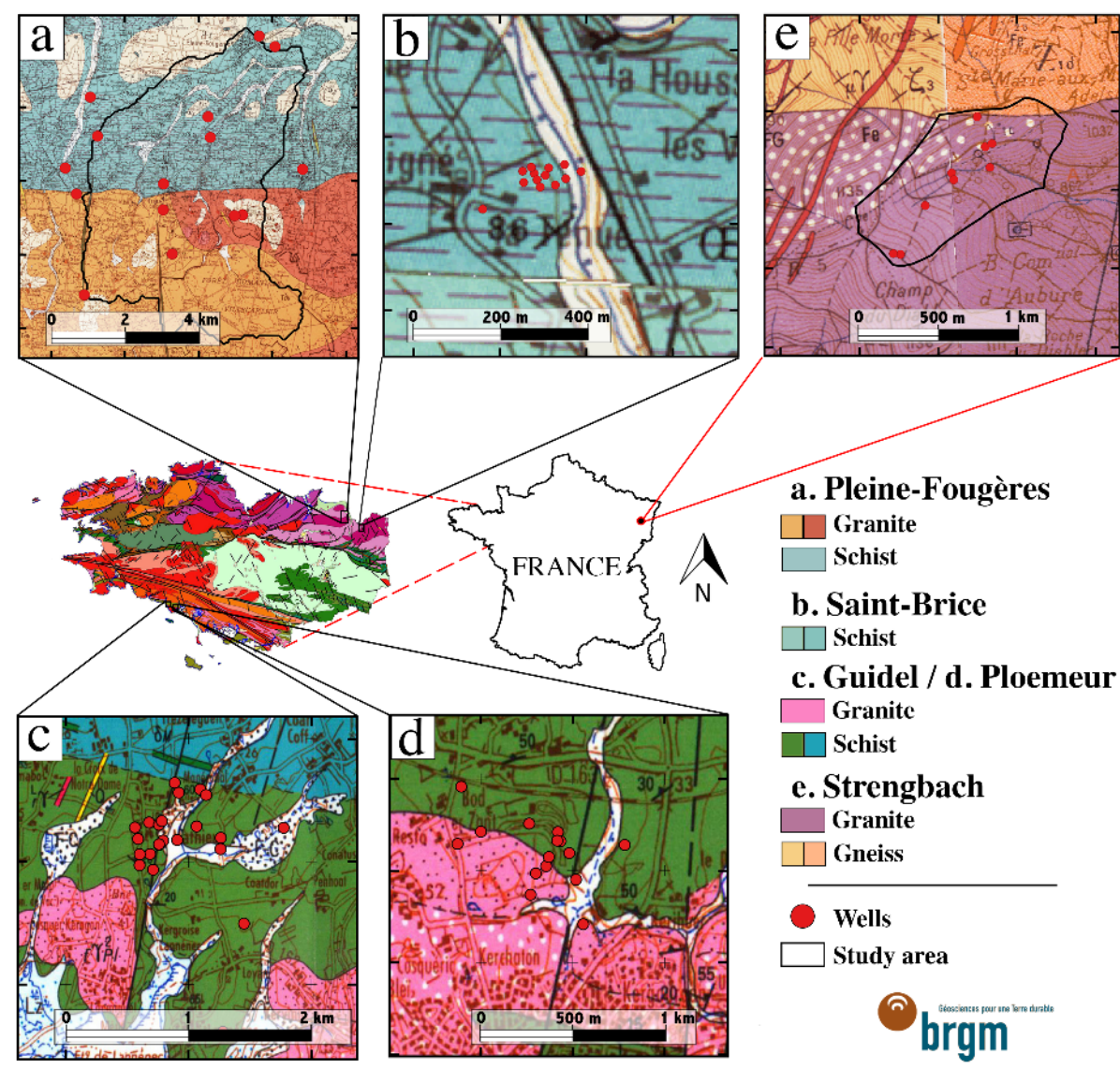

173 Figure 3: Site locations on the geological map of Brittany (center-left) with detailed site maps of lithology

174 and well location for (a) Pleine Fougères, (b) Saint Brice (c) Guidel, and (e) Plœmeur, which is a pumping

175 site for drinking water supply. (d) Strengbach is a headwater located in the Vosges Mountains (east part of

176 France). Adapted from the Bureau de Recherches Géologiques et Minières (BRGM) data.

\subsection{Geochemical data}

For each catchment, we analyzed CFC-12, CFC-11, CFC-113, and DSi concentrations determined during field campaigns between 2001 and 2015. We only used sampling dates where DSi and at least one CFC were simultaneously measured. Because the sampling of DSi and CFCs is relatively straightforward (a filtered and acidified water sample for DSi and water collected in a stainless-steel vial for CFCs), there were multiple, spatially-distributed replicates for each catchment corresponding to different sampling wells or sampling campaigns (i.e. 32 replicates on average for each catchment, see Table 1). DSi was quantified 
185 as $\mathrm{H}_{4} \mathrm{SiO}_{4}\left(\mathrm{mg} \mathrm{L}^{-1}\right)$, from $0.2 \mu \mathrm{m}$ filtered and acidified samples by inductively coupled plasma 186 mass spectrometry (ICP-MS) at the Geoscience Rennes laboratory, with an uncertainty of $187 \pm 2 \%$ (Bouhnik-Le Coz et al., 2001; Roques et al., 2014b). CFC concentrations were measured 188 by purge and trap gas chromatography at the CONDATE EAU laboratory, at the OSUR in the 189 University of Rennes 1 (France), with a precision of $\pm 4 \%$ for high concentrations and $\pm 20 \%$ 190 for samples near the quantification limit (0.1 pmol L ${ }^{-1}$; Labasque et al. (2014); Labasque et al. 191 (2006)). Dissolved concentrations were converted to atmospheric partial pressures (pptv) with 192 Henry’s law, considering gas solubility and excess air effects (Busenberg and Plummer, 193 1992). Samples showing obvious contamination with CFCs were excluded from the analysis 194 (7\% of samples were above the maximum atmospheric concentration of CFC). 195 Contamination, which occurred primarily at the pumped catchment, was likely due to 196 manufacturing or maintenance activities in the nearby military airport. 


\begin{tabular}{|c|c|c|c|c|c|c|c|c|c|c|c|}
\hline Catchment ID & $\begin{array}{l}\text { Catchment } \\
\text { Name }\end{array}$ & $\begin{array}{l}\text { Area } \\
\left(\mathrm{km}^{2}\right)\end{array}$ & Lithology & $\begin{array}{l}\text { Number } \\
\text { of Wells }\end{array}$ & $\begin{array}{c}\text { Number of } \\
\text { data } \\
\text { (number of } \\
\text { data used) }\end{array}$ & $\begin{array}{c}\text { Percen- } \\
\text { tage of } \\
\text { polluted } \\
\text { data }\end{array}$ & $p H$ & $\begin{array}{l}\text { Water } \\
\text { Temper } \\
\text { ature } \\
\left({ }^{\circ} \mathrm{C}\right)\end{array}$ & $\begin{array}{l}\text { Unsaturate } \\
\text { d Zone } \\
\text { Thickness } \\
\text { (m) }\end{array}$ & $\begin{array}{l}\text { Supplementary } \\
\text { Information }\end{array}$ & References \\
\hline $\begin{array}{l}\text { Agricultural } \\
\text { catchment } 1\end{array}$ & $\begin{array}{l}\text { Pleine } \\
\text { Fougères }\end{array}$ & 35 & $\begin{array}{c}\text { Granite (50\%) } \\
\text { and Schist } \\
\text { (50\%) }\end{array}$ & 18 & $21(20)$ & $0 \%$ & $5.2-7.2$ & $11-14$ & - & $\begin{array}{c}\text { Moderate } \\
\text { agricultural inputs }\end{array}$ & (Kolbe et al., 2016) \\
\hline $\begin{array}{l}\text { Agricultural } \\
\text { catchment } 2\end{array}$ & Saint Brice & 1 & Mainly Schist & 11 & $48(45)$ & $6 \%$ & $5.3-7.1$ & $12-14.6$ & $2.2-5.1-9.4$ & $\begin{array}{c}\text { Moderate } \\
\text { agricultural inputs } \\
\end{array}$ & (Roques et al., 2014b) \\
\hline $\begin{array}{l}\text { Agricultural } \\
\text { catchment } 3\end{array}$ & Guidel & 2.9 & Schist & 10 & $18(18)$ & $0 \%$ & - & $14-14.7$ & $0.5-5.3-18$ & $\begin{array}{c}1 \mathrm{~km} \text { from the sea - } \\
\text { Moderate } \\
\text { agricultural inputs }\end{array}$ & $\begin{array}{l}\text { (Bochet, 2017; Bochet } \\
\text { et al., under revision) }\end{array}$ \\
\hline $\begin{array}{l}\text { Pumped } \\
\text { catchment }\end{array}$ & Plomeur & 2.5 & $\begin{array}{c}\text { Granite and } \\
\text { Schist }\end{array}$ & 16 & $65(58)$ & $11 \%$ & $5.4-6.5$ & $12-17.3$ & $7-12-30$ & Pumping site & $\begin{array}{c}\text { (Le Borgne et al., 2006; } \\
\text { Leray et al., 2012) }\end{array}$ \\
\hline $\begin{array}{l}\text { Mountainous } \\
\text { catchment }\end{array}$ & Strengbach & 0.8 & Granite & 11 & $17(17)$ & $0 \%$ & $5.6-7$ & 7.6-9.3 & $0-2.5-6$ & $\begin{array}{c}\text { Mountainous } \\
\text { headwater (Vosges) }\end{array}$ & $\begin{array}{l}\text { (Chabaux et al., 2017; } \\
\text { Viville et al., 2012) }\end{array}$ \\
\hline
\end{tabular}

197 Table 1: Characteristics of the study sites. The sites display contrast in size, lithology, and geochemical conditions especially regarding water temperature. For the

198 unsaturated zone thickness, the minimum, average and maximum thickness of the unsaturated zone (m) are reported. 


\section{Modelling residence times and silicate weathering rates}

To test our regional uniformity hypothesis, we simultaneously inferred residence times and silicate weathering rates for all five catchments, using data from the spatially distributed replicates within each catchment to derive representative weathering rates. We developed a standardized methodology requiring minimal a priori information to calibrate the lumped parameter models for the determination of RTDs. CFCs and DSi concentrations were jointly used to calibrate the lumped parameter models for each replicate (i.e. well), while weathering rates were optimized for each catchment to minimize the overall mismatch between modeled and measured concentrations. Following this procedure, silicate weathering rates were derived from DSi concentrations calibrated with CFC concentrations, which showed broad variability in mean residence time among sites.

Because CFC concentrations depend primarily on the date of groundwater recharge, while DSi concentration depends on water-rock interactions, these two tracers potentially contain complementary information about RTDs. In the following sections, we present the assumptions about weathering and types of RTDs, and then detail the calibration strategy

214 aiming at determining weathering at the scale of the catchment and RTD properties for each 215 well.

\subsection{Weathering assumptions}

Chemical weathering of silicate minerals is the net result of the dissolution of primary

218 silicate minerals minus the precipitation of secondary mineral formation (Anderson and 219 Anderson, 2010). To model the effect of residence times on overall observed DSi concentrations, we considered that precipitation and dissolution rate constants lead to a net

221 weathering rate $\alpha\left[\mathrm{mg} \mathrm{L}^{-1} \mathrm{yr}^{-1}\right.$, which corresponds to the enrichment rate of groundwater in 222 DSi. 
At the intermediate scale (10s to 100 s of meters), this net weathering rate encounters a rapid transition from surface-limited to transport-limited weathering. During this transition, weathering rates may differ in the unsaturated zone as minerals differ from the deeper unaltered zone and water contains lower DSi concentrations, which together favor surface reaction-limited processes. While we did not estimate unsaturated zones weathering rates, we did account for differences in DSi concentration at the water table (see next paragraph). Timebased observations in crystalline formations show that weathering rates do not depend on residence times for groundwater older than few months to decades, due to transport and thermodynamic controls, which sustain the weathering (Ackerer et al., 2018; Maher, 2010; White and Brantley, 2003). Given that the shallow crystalline aquifers investigated in this 233 study have CFC apparent ages greater than 25 years (Ayraud, 2005; Ayraud et al., 2008; 234 Kolbe et al., 2016; Leray et al., 2012; Roques et al., 2014a), we assumed that $\alpha$ stays constant i.e. that the net weathering follows a zero-order kinetic reaction. assumed to lead to an initial DSi concentration $C_{S i}^{0}$, which does not depend on the 238 groundwater residence time $t$ (i.e. the amount of time water spends in the unsaturated zone 239 may be unrelated to the subsequent residence time in the aquifer). $t$ only represents the 240 residence time in the aquifer because it is inferred from CFC concentrations, which 241 equilibrate at the water table (Figure 2a). Therefore, assuming a constant weathering rate $\alpha$ 242 and an initial DSi concentration $C_{S i}^{0}$ reached at the water table results in a linear expression of 243 the DSi concentration as a function of the residence time $t$ [yr]: 


$$
C_{S i}^{p r o d}(t)=\left\{\begin{array}{lll}
\alpha t+C_{S i}^{0} & \text { if } t<t_{\max } \\
C_{S i}^{\max }=\alpha t_{\max }+C_{S i}^{0} & \text { if } t \geq t_{\max }
\end{array},\right.
$$

244 where $t_{\max }$ is the time at which groundwater becomes saturated in DSi (i.e. precipitation or 245 removal equals dissolution). Indeed, at larger scale, mineral equilibrium can be reached. 246 However, recent hydrogeochemical modeling of weathering in the mountainous catchment 247 showed that silica equilibrium is not reached until kilometers of transport, much farther than 248 typical flow distance between recharge areas and sampling wells or surface water features 249 (Ackerer et al., 2018; Kolbe et al., 2016; Lucas et al., 2017). Additionally, for many 250 catchments there is a negligible contribution of groundwater with residence times longer than 251100 years (age at which the groundwater is likely to encounter DSi saturation) as shown by 252 the presence of CFCs in the groundwater of these catchments. Therefore, $C_{S i}^{\text {prod }}$ only depends on residence time $t$, weathering rate $\alpha$ and initial DSi concentration $C_{S i}^{0}$ at the water table.

\subsection{Modeling groundwater mixing}

Multiple geological, topographical, and hydraulic factors influence RTDs. Distributed groundwater flow and transport models were previously developed for the agricultural catchment 1 and the pumped catchment, showing that the general shape of the RTDs can be well approximated by an inverse Gaussian function in most cases (Kolbe et al., 2016; Marçais et al., 2015). Inverse Gaussian distributions have proved especially efficient for providing accurate predictions of distribution quantiles and integrated renewal times within the time range where information can theoretically be extracted from CFC tracers (i.e. 0-70 years, Figure 1). Previous studied sites have also shown that the choice of the lumped parameter model is not critical as long as it has two parameters and is unimodal (Eberts et al., 2012; Kolbe et al., 2016; Marçais et al., 2015). Inverse Gaussian distributions have the additional 
265 advantage of being physically grounded as they are the solution of the $1 \mathrm{D}$ advection 266 dispersion equation:

$$
f_{\mu, \sigma}(t)=\frac{1}{\sigma} \sqrt{\frac{\mu^{3}}{2 \pi t^{3}}} \exp \left(-\frac{\mu(t-\mu)^{2}}{2 \sigma^{2} t}\right),
$$

267 where $t$ is the residence time, $\mu$ is mean time and $\sigma$ is the standard deviation. The two 268 degrees of freedom of an inverse Gaussian distribution are sufficient to adapt to most 269 observed hydraulic conditions found in upland sites, which show narrow distributions similar 270 to Dirac distributions, and in lowland sites near the surface flow outlet, which express more 271 exponential shapes (Haitjema, 1995). We therefore used inverse Gaussian distributions for all 272 catchments, though a different lumped parameter model's choice could be easily implemented 273 if hydraulic conditions required it (Leray et al., 2016).

275 the mean residence time $\mu$ and the standard deviation $\sigma$ of the distribution. For a given 276 Inverse Gaussian RTD $f_{(\mu, \sigma)}$, the concentrations in CFCs can be modeled as:

$$
\begin{aligned}
& C_{C F C-12}^{\mathrm{mod}}\left(t_{s}, \mu, \sigma\right)=\int_{0}^{+\infty} \mathfrak{C}_{C F C-12}\left(t_{s}-u\right) \cdot f_{(\mu, \sigma)}(u) d u \\
& C_{C F C-11}^{\mathrm{mod}}\left(t_{s}, \mu, \sigma\right)=\int_{0}^{+\infty} \mathfrak{C}_{C F C-11}\left(t_{s}-u\right) \cdot f_{(\mu, \sigma)}(u) d u, \\
& C_{C F C-113}^{\mathrm{mod}}\left(t_{s}, \mu, \sigma\right)=\int_{0}^{+\infty} \mathfrak{C}_{C F C-113}\left(t_{s}-u\right) \cdot f_{(\mu, \sigma)}(u) d u
\end{aligned}
$$

277 where $u$ is the residence time, $t_{s}$ is the sampling date, $t_{s}-u$ is the recharge date (when the 278 water reaches the water table) and $\mathcal{C}_{C F C}$ is the corresponding CFC atmospheric time series

279 (Figure 1). Integrating over all the potential residence times, the product of the RTD $f_{(\mu, \sigma)}$ 
280 with the CFC concentration present at the water table at $t_{s}-u$ gives the modeled CFC

281 concentration. Similarly, the modeled concentration in DSi can be expressed as:

$$
C_{S i}^{\mathrm{mod}}\left(\alpha, C_{S i}^{0}, \mu, \sigma\right)=\int_{0}^{+\infty} C_{S i}^{\text {prod }}\left(\alpha, C_{S i}^{0}, u\right) \cdot f_{(\mu, \sigma)}(u) d u,
$$

282 where $C_{S i}^{\text {prod }}$ is the DSi concentration produced during the residence time $u$ via weathering 283 (equation (1)). Equations (3) and (4) give the modeled concentrations of CFCs and DSi, 284 which depend on the LPM parameters $(\mu, \sigma)$, and on the catchment-based weathering 285 parameters $\left(\alpha, C_{S i}^{0}\right)$, related to site characteristics.

\section{$286 \quad 3.3$ Calibration strategy: inferring conjointly RTDs and silicate weathering rates}

With $N$ wells on a given catchment and $N$ concentrations of CFCs and DSi $\left(C_{C F C-12_{k}}^{\text {mes }}, C_{C F C-11_{k}}^{\text {mes }}, C_{C F C-113_{k}}^{\text {mes }}, C_{S_{i_{k}}}^{\text {mes }}\right)_{1 \leq k \leq N}$, the calibration strategy consisted in optimizing together (i.e. for the $N$ datasets) the weathering rate $\alpha$, the initial concentration of DSi $C_{S i}^{0}$, and the best inverse Gaussian LPMs $\left(\mu_{k}, \sigma_{k}\right)_{1 \leq k \leq N}$ for each of the $N$ wells. We defined the

291 following objective function to optimize the calibration: 


$$
\begin{gathered}
\Phi\left(\alpha, C_{S i}^{0}, \mu_{1}, \sigma_{1}, \ldots, \mu_{N}, \sigma_{N}\right)= \\
\frac{1}{3 N} \sum_{k=1}^{N}\left\lceil\left|\tilde{C}_{S i \quad k}^{m e s}-\tilde{C}_{S i \quad k}^{\text {mod }}\left(\alpha, C_{S i}^{0}, \mu_{k}, \sigma_{k}\right)\right|+\right.
\end{gathered}
$$

$\min \tilde{C}_{C F C-12 k}^{\text {mes }}-\tilde{C}_{C F C-12 k}^{\text {mod }}\left(t_{s_{k}}, \mu_{k}, \sigma_{k}\right)+\tilde{C}_{C F C-11 k}^{\text {mes }}-\tilde{C}_{C F C-11 k}^{\bmod }\left(t_{s_{k}}, \mu_{k}, \sigma_{k}\right)$,

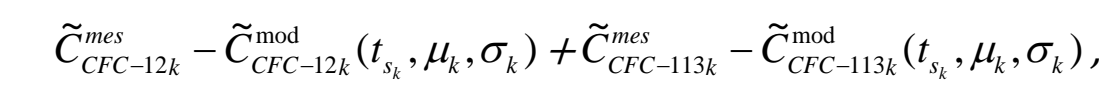

$\tilde{C}_{C F C-11 k}^{\text {mes }}-\tilde{C}_{C F C-11 k}^{\text {mod }}\left(t_{s_{k}}, \mu_{k}, \sigma_{k}\right)+\tilde{C}_{C F C-113 k}^{\text {mes }}-\tilde{C}_{C F C-113 k}^{\text {mod }}\left(t_{s_{k}}, \mu_{k}, \sigma_{k}\right)$

292 where $\tilde{C}$ are the standardized and centered values of $C$. In equation (5), the minimum 293 conveys that we only retain the two most coherent CFC concentrations with their respective 294 modeled counterparts out of the three CFC concentrations available (Jurgens et al., 2012).

Because of some non-convexity of the objective function $\Phi$, we use a two-step optimization method with an initial calibration of $\left(\alpha, C_{S i}^{0}\right)$ with the simulated annealing Monte-Carlo method in MATLAB (Ingber, 2000), and a second gradient-based Levenberg298 Marquardt optimization to complete the reduction of the set of parameters. Using this methodology, weathering rates were compared among the catchments to test for regional differences in weathering rate.

\section{Results}

We first report observed CFC and DSi concentrations for the different catchments and

303 then use the methodology presented in section 3 to derive the catchment-level weathering rates and individual well RTDs. 


\subsection{Observed CFC and DSi concentrations}

The relationship between CFCs and DSi was generally negative, though the strength of the relationship and range of values varied by catchment (see Figure 4). Given the theoretical relationship between CFCs and DSi, Figure 5 shows the concentrations of CFC-12 and DSi that can be reached with Inverse Gaussian RTDs, whatever their mean and standard deviations in the range of 0-100 years for the two silicate weathering rates, i.e. $\left(\alpha=0.25 \mathrm{mg} \mathrm{L}^{-1} \mathrm{yr}^{-1}, C_{S i}^{0}=4 \mathrm{mg} \mathrm{L}^{-1}\right) \quad$ and $\quad\left(\alpha=0.5 \mathrm{mg} \mathrm{L}^{-1} \mathrm{yr}^{-1}, C_{S i}^{0}=8 \mathrm{mg} \mathrm{L}^{-1}\right) . \quad$ Each point represents an Inverse Gaussian RTD with specific parameters. Sampling well data of the agricultural catchment 1 are shown as green triangles on the same plot for illustrative purposes and the best RTD associated for each well sampled is represented among the different Inverse Gaussian RTD by orange circles. The lower weathering scenario ( $\alpha=0.25 \mathrm{mg} \mathrm{L}^{-1} \mathrm{yr}^{-1}, C_{S i}^{0}=4 \mathrm{mg} \mathrm{L}^{-1}$ ) explained much of the variability observed in the CFC-12 and DSi concentrations, suggesting that it is closer to the in situ rate. The difference between the two envelopes underlines the high sensitivity of the weathering model and gives some preliminary illustration of the capacity of extracting meaningful weathering properties. 

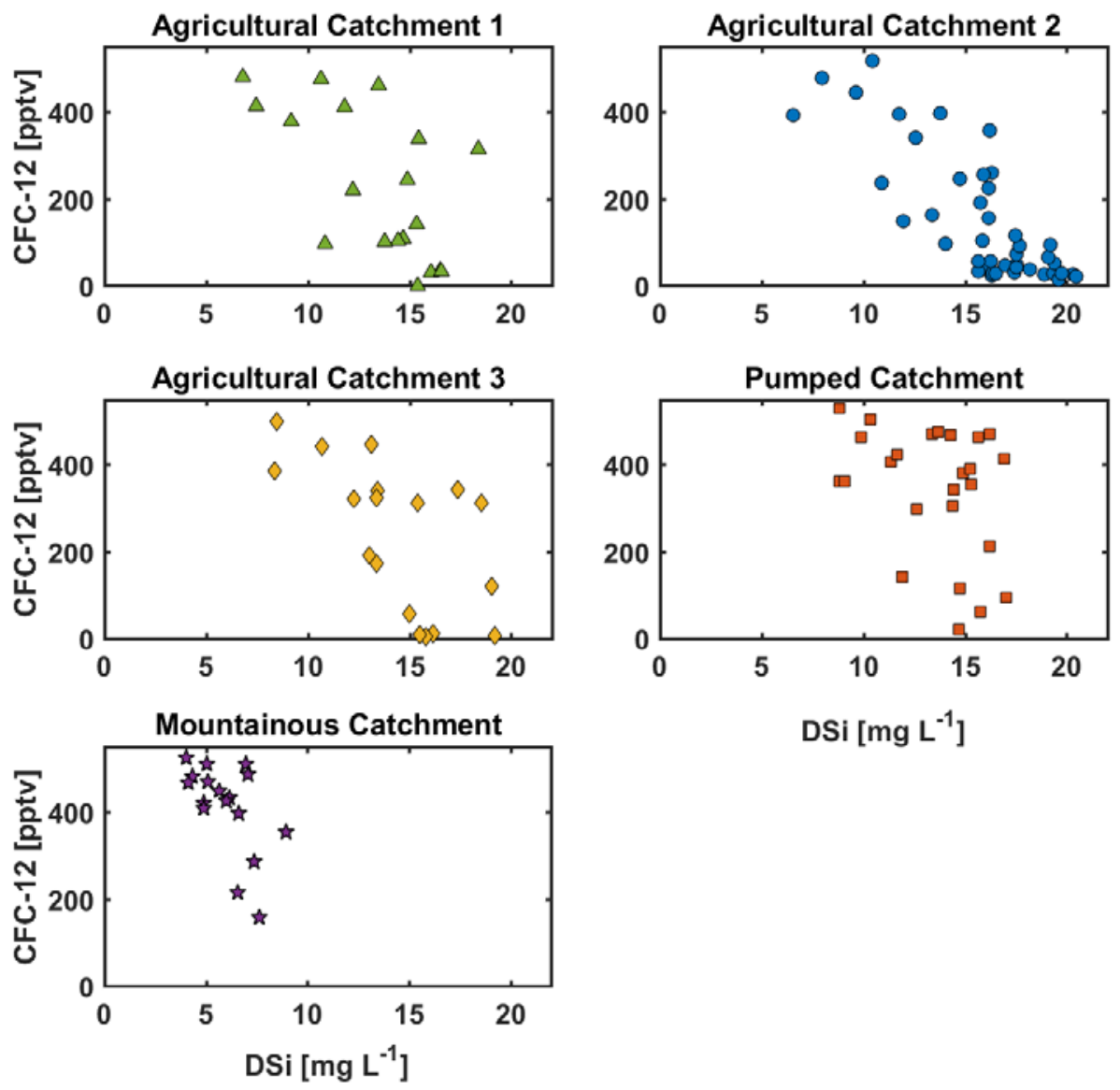

DSi $\left[\mathrm{mg} \mathrm{L}^{-1}\right]$

Figure 4: CFC-12 vs DSi concentrations obtained for each of the field sites.

\subsection{Catchment-based optimal weathering rates}

We applied the same optimization method for each of the 5 catchments. $\rho$ (the average

324 model error) varied significantly among catchments, with relatively small values (below 0.25 )

325 for most of the catchments, but higher values for the pumped catchment ( $\rho=1.64$; Table 2).

326 Optimal weathering rates were relatively similar among catchments, especially for the

327 agricultural catchments, which ranged from 0.20 to $0.23 \mathrm{mg} \mathrm{L}^{-1} \mathrm{yr}^{-1}$ (CV $=7 \%$ ), demonstrating

328 regional consistency among different rock types. The weathering rate was significantly slower

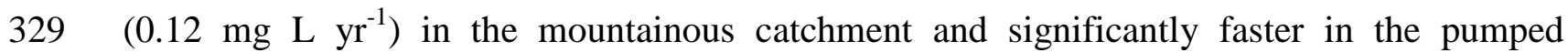
330 catchment $\left(0.31 \mathrm{mg} \mathrm{L} \mathrm{yr}^{-1}\right)$. 


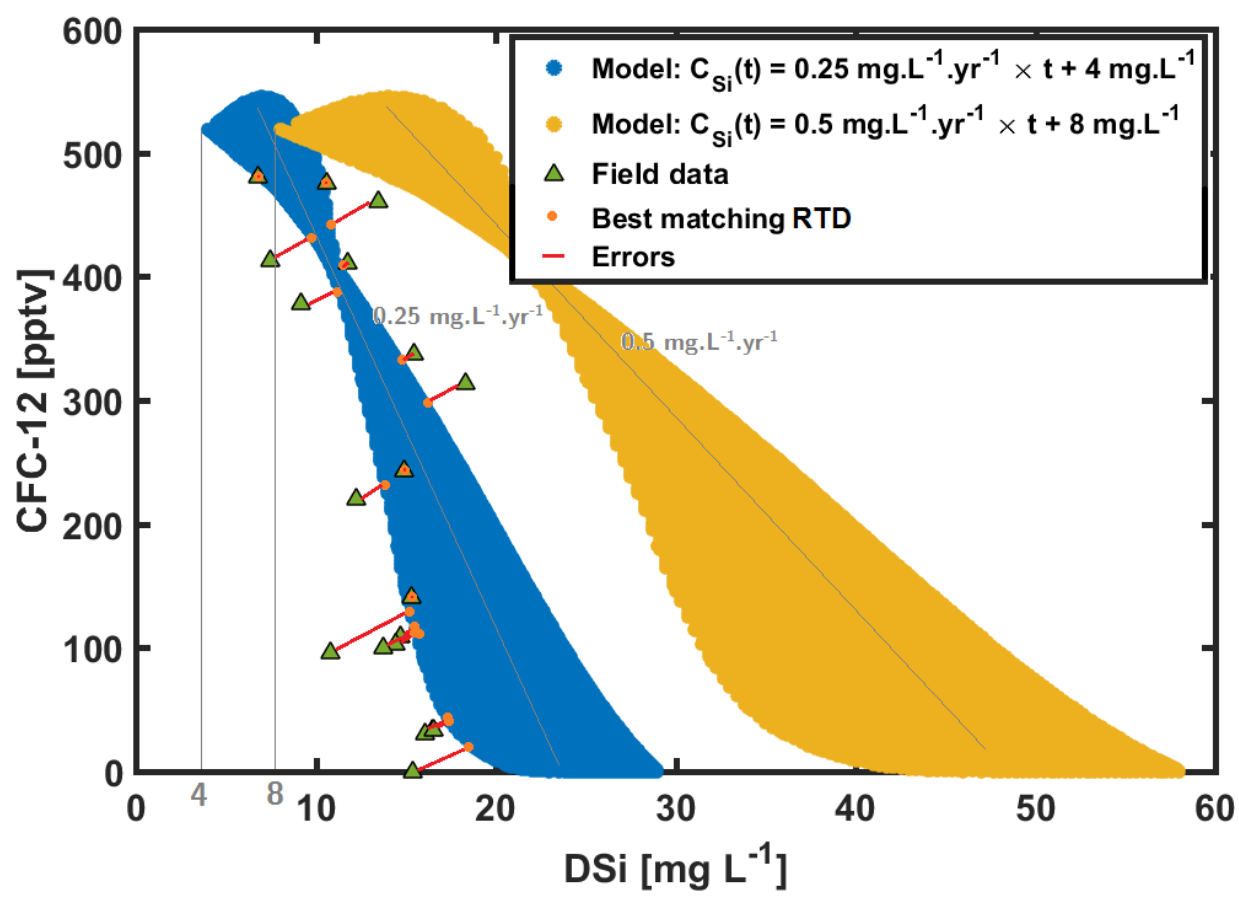

332 Figure 5: Calibration methodology. For each dataset representative of one site (Field data), the equation of weathering (1) is optimized by minimizing the sum of the square errors between the well data and their best matching Inverse Gaussian RTD in the RTD model ensemble. Two models ensemble are represented: the blue one with $\left(\alpha, C_{S i}^{0}\right)=\left(0.25 \mathrm{mg} \mathrm{L}^{-1} \mathrm{yr}^{-1}, 4 \mathrm{mg} \mathrm{L}^{-1}\right)$ and the yellow one with $\left(\alpha, C_{S i}^{0}\right)=\left(0.5 \mathrm{mg} \mathrm{L}^{-1} \mathrm{yr}^{-1}\right.$, $8 \mathrm{mg} \mathrm{L}^{-1}$ ). Notice how $C_{S i}^{0}$ controls the horizontal position of the RTDs models in the (CFC, DSi) plot, especially for the young fraction of the RTDs (high CFC-12, low DSi) while $\alpha$ controls the overall DSi spreading of the models ensemble, especially for the old fraction of the RTDs (low CFC-12, high DSi).

340 variation of $19 \%$ among catchments. On the extremes, the mountainous catchment showed an 341 initial DSi of $2.9 \mathrm{mg} \mathrm{L}^{-1}$ while the pumped catchment had an initial concentration of

$3425.0 \mathrm{mg} \mathrm{L}^{-1}$, likely due to differences in weathering in the unsaturated zone.

\begin{tabular}{|l|c|c|c|c|c|}
\hline Catchment & $\rho[-]$ & $\alpha\left[\mathrm{mg} \mathrm{L}^{-1} \mathrm{yr}^{-1}\right]$ & $C_{S i}^{0}\left[\mathrm{mg} \mathrm{L}^{-1}\right]$ & mean $(\mu)[y r]$ & $\operatorname{mean}(\sigma)[y r]$ \\
\hline Agricultural catchment 1 & 0.12 & 0.20 & 4.0 & 52 & 39 \\
\hline
\end{tabular}




\begin{tabular}{|l|c|c|c|c|c|}
\hline Agricultural catchment 2 & 0.26 & 0.22 & 3.8 & 60 & 32 \\
\hline Agricultural catchment 3 & 0.23 & 0.23 & 4.3 & 52 & 49 \\
\hline Pumped catchment & 1.64 & 0.31 & 5.0 & 40 & 53 \\
\hline Mountainous catchment & 0.19 & 0.12 & 2.9 & 30 & 59 \\
\hline
\end{tabular}

343 Table 2: Results obtained from the calibration. $\rho$ is the residual (see equation (1)). $\alpha$ is the weathering

344 rate in $\mathrm{mg} \mathrm{L}^{-1} \mathrm{yr}^{-1}, C_{S i}^{0}$, the initial DSi concentration in $\mathrm{mg} \mathrm{L}^{-1}$. The two last columns present some

345 statistics about the parameters of the inverse Gaussian distributions optimized for each well: the average of

346 the mean residence time $\mu$ in years and the average of the standard deviation $\sigma$ in years of the residence

347 time distributions for each catchment.

$348 \quad 4.3 \quad$ Models of RTDs

349 The largest differences between well-level RTDs occurred in the agricultural catchment

3502 (Figure 6). The wells intersecting deep productive fractures had high DSi concentration and

351 low CFC concentrations (Figure 4) and displayed broad RTDs between 40 and 100 years

352 (Table 2 and yellow and purple curves in Figure 6). The low CFC concentrations

353 corresponded with the modeled RTDs, which indicated limited modern water (less than 15 to

35420 years’ old). High DSi concentration requires much longer timescales and can be modeled

355 as well by the contribution of residence times above 40 years. The water residence time

356 distributions of the shallow wells (blue and red curves of Figure 6) showed significantly

357 younger water due to the lack of the old water contributions coming from deeper fractures

358 (Figure 6). 


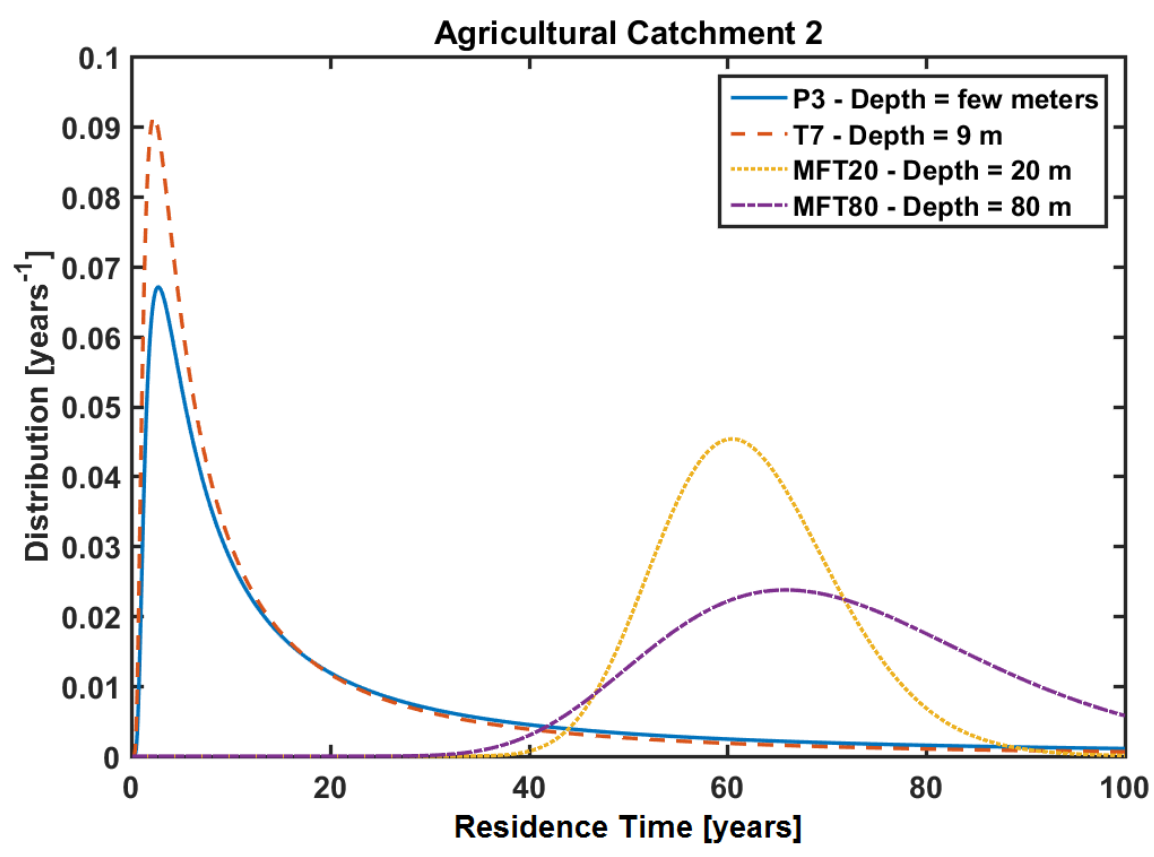

Figure 6: Illustration of the calibrated Inverse Gaussian RTD obtained on the agricultural catchment 2 (Saint Brice). The wells lying in the shallowest part of the aquifers have small residence times and exponential shapes. The wells lying in the deepest part of the aquifer display some skewed distributions.

To get an idea of the type of RTDs obtained for the other catchments, we also compared some statistics of the RTDs between sites, obtained with the optimization reported in Table 2. years for the mountainous catchment and 60 years for the agricultural catchment 2.

\subsection{Relations between DSi and mean residence times}

A byproduct of the calibration of the inverse Gaussian lumped parameter model for the DSi and CFC concentrations was the relation between the modeled mean residence times and the observed DSi concentrations here shown for the three agricultural catchments located in

371 Brittany (Figure 7). For each catchment, the relation appeared to be linear, reinforcing the consistency between the observed and modeled concentrations, and providing support for the assumptions of the modeling approach. More specifically, the direct proportionality of the 
zero-order kinetic reaction (equation (1)). The linear relations were also similar among catchments with coefficients of variation of respectively $7 \%$ and $6 \%$, for the different weathering rates and the initial DSi concentration of the agricultural catchments.

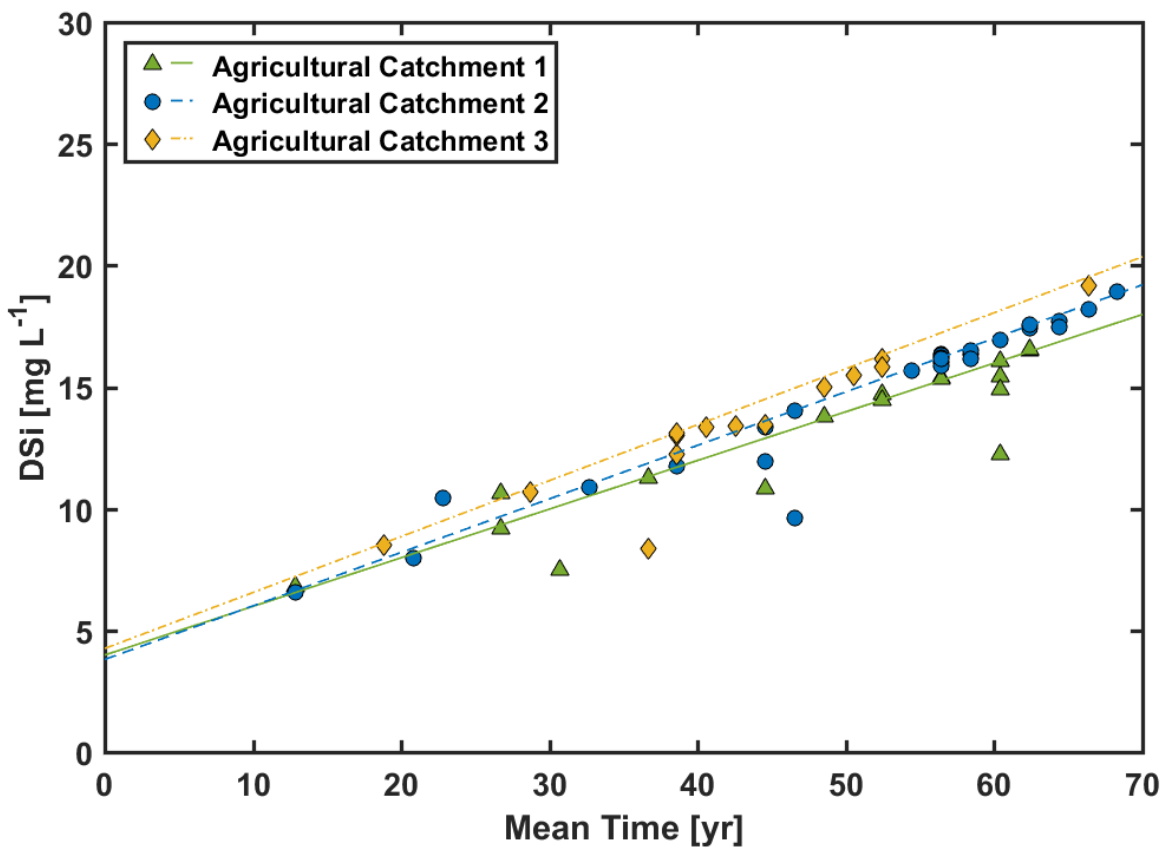

379 Figure 7: Measured DSi concentration versus the optimized mean residence time of the inverse Gaussian lumped distribution for three of the Brittany sites. Straight lines represent the optimized weathering law for each of the sites. Note that it fits the measurements. Considering a constant weathering rate allows direct interpretation of DSi apparent ages into mean residence times.

We compared these modeled mean residence times obtained with the CFC and DSi concentrations with the mean residence times calibrated only with the CFC concentrations residence times obtained were quite consistent, especially for mean residence times ranging between 0 and 50 years. For such a time range, a linear regression gives $\mu_{D S i-C F C s}=$ $1.03 \mu_{C F C s}$ with a $\mathrm{R}^{2}$ of 0.36 . 


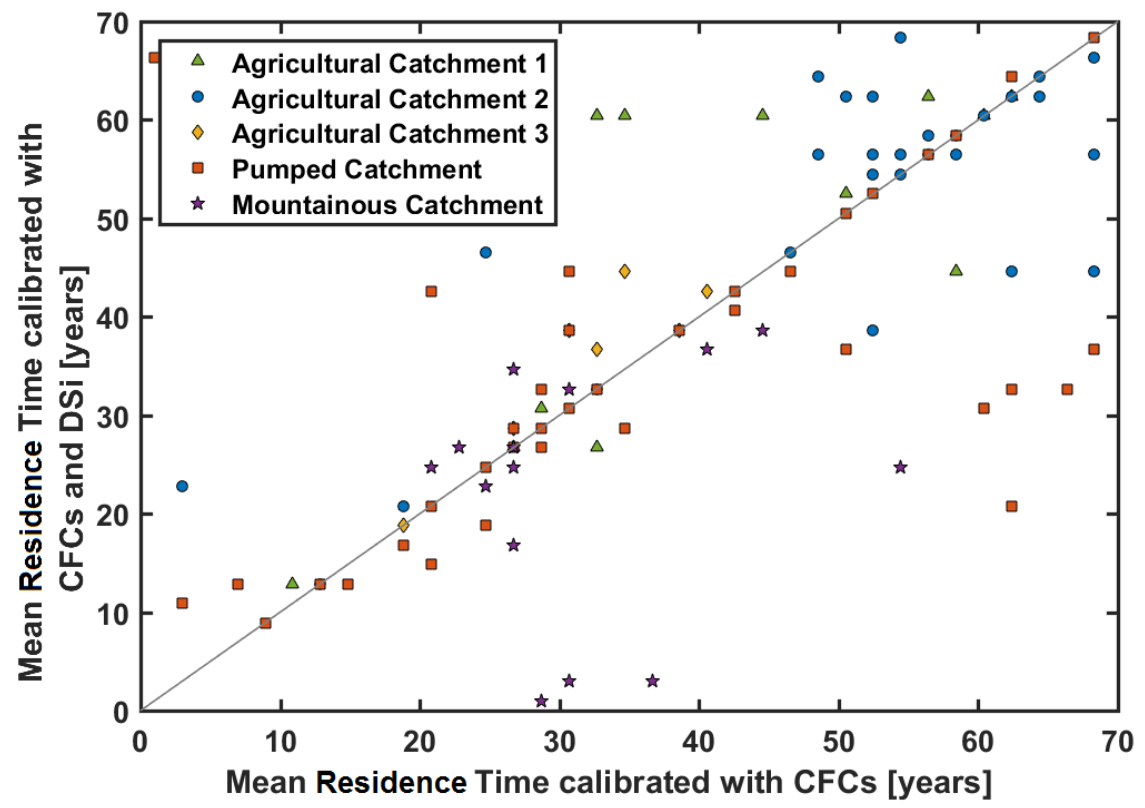

391 Figure 8: Comparison between the mean residence time obtained with CFCs and DSi concentrations with those obtained only with the CFC concentrations.

393

\section{Discussion}

While DSi has been used as a site-specific indicator of groundwater residence time (Burns et al., 2003; Kenoyer and Bowser, 1992; Morgenstern et al., 2010; Peters et al., 2014), it was unknown how consistent silica weathering rates were, and consequently if DSi could be a useful tracer at regional scales. In this study, we evaluated the use of DSi for groundwater dating at four catchments in Brittany and one catchment in the Vosges Mountains. The data and our simulations supported the hypothesis that silica weathering can be described by a zero-order kinetic reaction at the catchment scale, and we calibrated silicate weathering laws using CFC atmospheric tracers. We found that DSi provided complementary information to CFC atmospheric tracers on RTDs. The relative stability of weathering rates among the Brittany agricultural catchments validates the use of DSi as a regional groundwater age proxy. We discuss below how these weathering rates may be modified by climatic context (from the oceanic conditions of Brittany to the mountainous climate of the Vosges) and by external 
406 factors, e.g. groundwater abstraction. Finally, we discuss the use of DSi for evaluating

residence times in unsaturated zones and compare these optimized silicate weathering rates to weathering rates estimated in previous studies.

\subsection{Practical use of DSi as a proxy of groundwater residence time}

DSi concentration appears to be a highly complementary tracer to atmospheric tracers such as CFCs. For example, at the agricultural catchment 2 (Figure 6), the comparison of wells of different depths (shallow wells for P3 and T7, and deeper wells for MFT 20 and MFT80) revealed that DSi concentration can infer the RTD even when CFCs are not discriminating because they are below their detection limit for older ages ( $>70$ years) or during the flat portion of their atmospheric trend (i.e. the last 0-20 years). These time ranges where CFCs are less informative are further exacerbated by the widening of the concentration area reachable by the inverse Gaussian function towards lower and higher CFC-12 concentration (Figure 5). For such CFC range (for example, for CFC-12 between 450 and $550 \mathrm{pptv}$ and between 0 and $50 \mathrm{pptv}$ ), DSi is particularly useful to better characterize RTD. The comparison between the modeled mean residence times and those calibrated only with CFCs (Figure 8) also displayed an increased consistency for the time range between 0 and 50 years. For mean residence times above 50 years, DSi appears to give complementary information to mean residence times from CFCs as depicted by the increased variability of mean residence times around the identity line $y=x$.

The bulk linear relation for weathering rate (equation (1)) is also of interest for dating purposes as DSi concentrations can be seen as a direct proxy of the mean residence time

(Figure 7), which is not the case for other tracers such as CFCs (Figure 1) (Leray et al., 2012; Marçais et al., 2015; Suckow, 2014). While this result has been obtained with a specific Lumped Parameter Model (inverse Gaussian), it is generally applicable for a broad range of 
430

distributions as it relies on the zero-order weathering assumption that leads to a linear dependence of the DSi concentration on residence times (equation (1)).

Even if the small residuals obtained in Table 2 indicate that the inverse Gaussian model may be appropriate for RTDs, other types of distributions, like the Gamma distribution, can be tested to assess the sensitivity of the LPM choice to the RTD-related prediction. For the agricultural catchment 1 and the pumped catchment, shapes of the Inverse Gaussian LPM as well as the statistics obtained regarding the optimized RTDs (Table 2) are consistent with results obtained synthetically from calibrated 3D flow and transport models developed for these aquifers (Kolbe et al., 2016; Leray et al., 2012).

The 5 to 100 years' time range of the RTDs observed here is the most favorable case for using DSi for groundwater dating since it leads to thermodynamic-limitation conditions which sustains chemical weathering (Maher, 2010). Even though weathering rates $\alpha$ might be quite variable between different crystalline rock types, the fluid-rock contact time controls the evolution of DSi concentrations for residence times ranging from years to decades (5-100 years) where dissolution is the dominant process. On the contrary, attainment of the mineral equilibrium restricts the use of DSi for estimating longer residence times (>300 years) when dissolution is balanced by re-precipitation (Edmunds and Smedley, 2000).

\subsection{Stability of silica weathering rates at the regional scale}

\subsubsection{DSi as a robust regional groundwater age proxy}

Our results indicate that DSi can be used as groundwater age tracing tool in relatively diverse geologic contexts, as indicated by the consistency of the weathering rates for the different Brittany catchments (Figure 7). This homogeneity suggests that only a few mineral phases are responsible for silica production in the studied residence-time range; typically phyllosilicates, plagioclase, and accessory minerals such as apatite are the major sources of 
454 silica (Aubert et al., 2001). Applying a uniform weathering rate $\left(0.22 \mathrm{mg} \mathrm{L}^{-1} \mathrm{yr}^{-1}\right)$ and initial 455 DSi concentration (4.0 $\left.\mathrm{mg} \mathrm{L}^{-1}\right)$ can provide a first order estimate of mean residence time, as 456 displayed by the blue curve presented in Figure 9 compared to the weathering rates of each of 457 the Brittany catchments displayed in Figure 7. The relatively small error associated with 458 catchment specific differences justifies the possible use of DSi as a regional groundwater 459 dating tracer, as long as a weathering law can be applied based on similar catchments or land 460 lithologies. If more complete modeling is available, the choice between weathering laws can 461 be bypassed by directly solving the mass balance of the geochemical water content (Burns et 462 al., 2003).

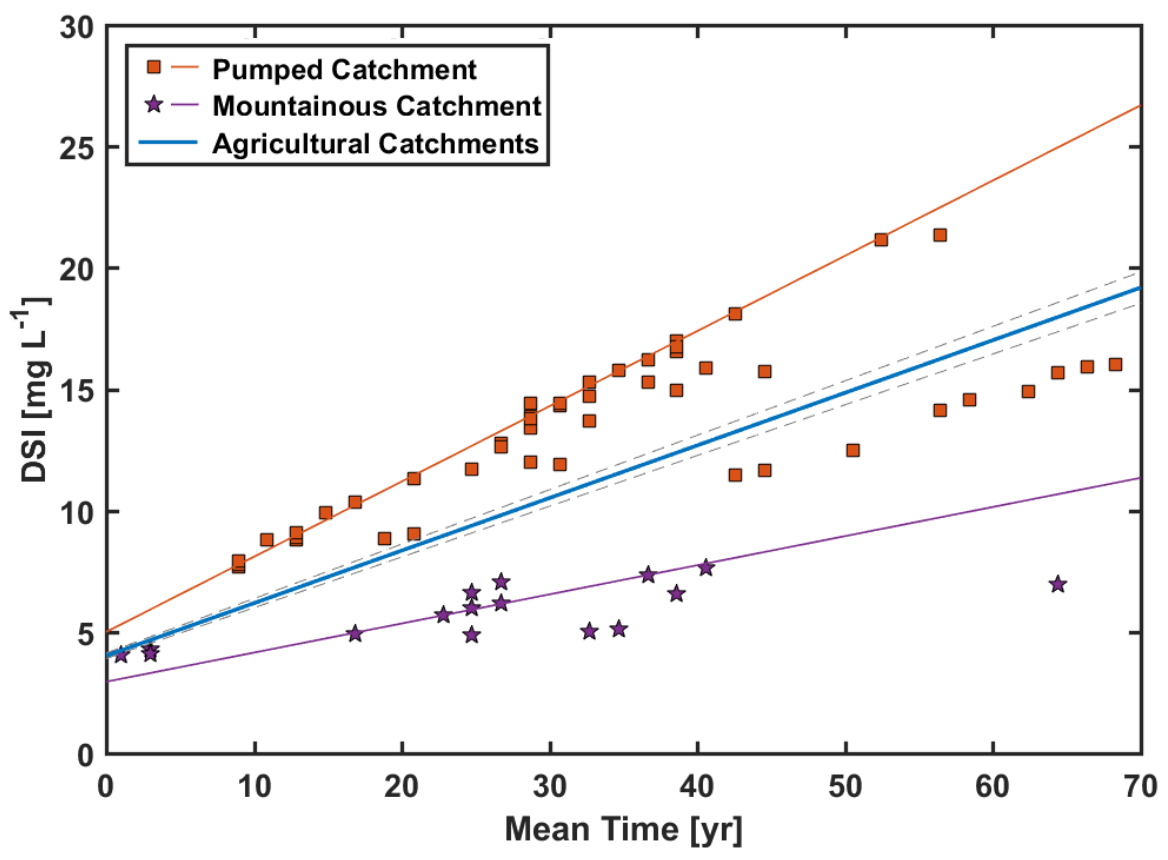

464 Figure 9: DSi concentrations versus the optimized mean residence time of the inverse Gaussian displayed for each wells for the mountainous and the pumped catchment. Straight lines represent the optimized weathering law for each of the sites. Note that it fits the measurements. Considering a constant weathering rate enables to indistinctly consider Si apparent ages and mean residence times.

Silicates are ubiquitous in most geological matrices, including crystalline and sedimentary rocks (Iler, 1979). There is some evidence for using DSi as a groundwater age 
470

471

472

473

474

475

476

477

478

479

480

481

482

483

484

485

486

487

488

489

490

491

492

493

proxy in other rock types (e.g. sedimentary rocks coming from glacial deposits, see section 5.4) (Becker, 2013; Kenoyer and Bowser, 1992). DSi concentration is widely measured and accessible through public observatories and databases (Abbott et al., 2018; De Dreuzy et al., 2006; Thomas et al., 2016b). While previous studies have shown dependency of weathering rates on lithology and climate (White and Blum, 1995; White et al., 1999; White et al., 2001), DSi might be considered a “contextual tracer”, allowing at least local and potentially regional groundwater dating (Beyer et al., 2016).

A major advantage of DSi is that it persists in open surface waters (e.g. lakes and streams), whereas other tracers of intermediate transit times such as ${ }^{3} \mathrm{H} / \mathrm{He}$ and CFCs quickly equilibrate with the atmosphere. Additionally, because artificial sources are few and background concentration is usually high, DSi is robust to contamination, unlike CFCs, which cannot be in contact with the atmosphere during sampling nor with any plastic surfaces (Labasque et al., 2014). However, uptake of DSi by some vegetation and diatoms could potentially limit the use of DSi in some environments especially during the growing season (beginning of summer)(Delvaux et al., 2013; Pfister et al., 2017). This uptake is more likely in large rivers systems where DSi spend enough time to be effectively captured by diatoms whereas it is less prone to occur in headwaters systems with much smaller stream residence times (Hughes et al., 2013). To track this potential additional process into account, diatom uptake could be modeled (Thamatrakoln and Hildebrand, 2008) and/or isotopic DSi ratios could be investigated to link in stream DSi concentration to mean transit time (Delvaux et al., 2013).

\subsubsection{Comparison between the agricultural catchments and the mountainous catchment}

Weathering rates were relatively constant within a given regional geological and climatic context (e.g. for the three catchments in Brittany), but they were significantly different from 
494 the mountainous catchment (Vosges Mountains). Differences in lithology could control overall weathering rates, but this was not supported by the observed homogeneity of the weathering rate across different lithologies (section 5.2.1). Acidity could not either explain this variability, as $\mathrm{pH}$ was comparable for all the catchments (Table 1). The lower rates in the mountainous catchment may be due to a difference in climatic conditions (i.e. temperature and rainfall) between Brittany and the Vosges Mountain (Table 1). The $\sim 3$ factor difference between DSi in the Vosges and Brittany could be explained by the combined effect of the groundwater temperature difference $\left(\sim 6^{\circ} \mathrm{C}\right)$ and precipitation difference ( $\sim 1.5$-fold). Indeed, temperature affects weathering rates by one order of magnitude from 0 to $25^{\circ} \mathrm{C}$ (White and Blum, 1995; White et al., 1999). This increase is further emphasized by increasing recharge fluxes, which is related to rainfall conditions. Another effect which could explain the difference for the mountainous catchment is lack of anthropogenic pressure related to agriculture. Brittany is a region of intensive agriculture characterized by high nitrogen loads, which induce soil acidification. High weathering rates have been observed related to fertilized additions (Aquilina et al., 2012a) which may also partially explain the Vosges-Brittany difference. Anyway, climatic and anthropogenic influences are not exclusive and may be combined to explain the high weathering rate difference.

\subsubsection{Effect of groundwater abstraction on the weathering rate}

The weathering law for heavily-pumped catchment in Plœmeur (orange line, Figure 9) displayed a substantially higher weathering rate $\left(0.31 \mathrm{mg} \mathrm{L}^{-1} \mathrm{yr}^{-1}\right)$ compared to the average Brittany weathering rate $\left(0.22 \mathrm{mg} \mathrm{L}^{-1} \mathrm{yr}^{-1}\right)$. This might be due to the presence of CFC contamination leading to artificially enriched CFC concentrations compared to their actual residence times. The pumped catchment is indeed especially vulnerable to CFC contaminations (Table 1). However, long-term monitoring of $\mathrm{CFC}$ and $\mathrm{SF}_{6}$ and ${ }^{3} \mathrm{H} /{ }^{3} \mathrm{He}$ measurements in this site makes the contamination hypothesis unlikely (Tarits et al., 2006). 
The difference is more likely explained by the facts that: $i$ ) high and long-term pumping has mobilized older waters (>100 years), which increase DSi concentrations without substantially altering CFC concentrations (only dilution effect) (Figure 4); ii) pumping leads to a renewal of groundwater flow paths with more reactive surfaces, leading to an increase of the reactive surface/groundwater ratio.

\subsection{Use of DSi for inferring residence times in the unsaturated zone}

We hypothesized that the differences in initial DSi concentration are due to residence time in the unsaturated zone, suggesting that DSi concentration at the groundwater table surface (or modeled intercepts) could be used to infer residence times in the unsaturated zone. Indeed the variability in $C_{S i}^{0}$ observed in Table 2 is correlated with the average unsaturated zone thickness (Table 1), a major, though not exclusive, control on the time spent in the unsaturated zone (Figure 10). The high $C_{S i}^{0}$ for the pumped catchment (5.0 mg L ${ }^{-1}$ ) could be due to pumping-induced drawdown of the water table, which significantly increases the unsaturated zone thickness. Likewise, the mountainous catchment has a much shallower water table depth, which might be related to the low initial DSi concentration (2.9 mg $\left.\mathrm{L}^{-1}\right)$. DSi could therefore be a tracer of the full residence time in both unsaturated and saturated zones. Yet, unless weathering rates in the unsaturated zone can be constrained, DSi estimates would remain qualitative. Through tracing experiments, Legout et al. (2007) estimated the residence time in the mobile-compartment of the unsaturated zone of the Kerrien catchment (South Brittany) as 2-3 $\mathrm{m} \mathrm{y}^{-1}$, which induces weathering rates about 4 times higher than in the saturated zone. However, the ratio mobile/immobile water is unknown but may represent a large fraction of groundwater with long residence-time that may contribute to high DSi. Because the unsaturated zone, including the base of the soil profile, is often the site of elevated rates of biogeochemical activity (e.g. nitrogen retention and removal) (Legout et al., 

2005) or storage, constraining the residence time of water and solutes in this zone would 2010). Our methodology is intermediary as it combines lumped residence time distributions

allow better estimation of catchment and regional-scale resilience to nutrient loading and overall ecological functioning (Abbott et al., 2016; Meter et al., 2016; Pinay et al., 2015).

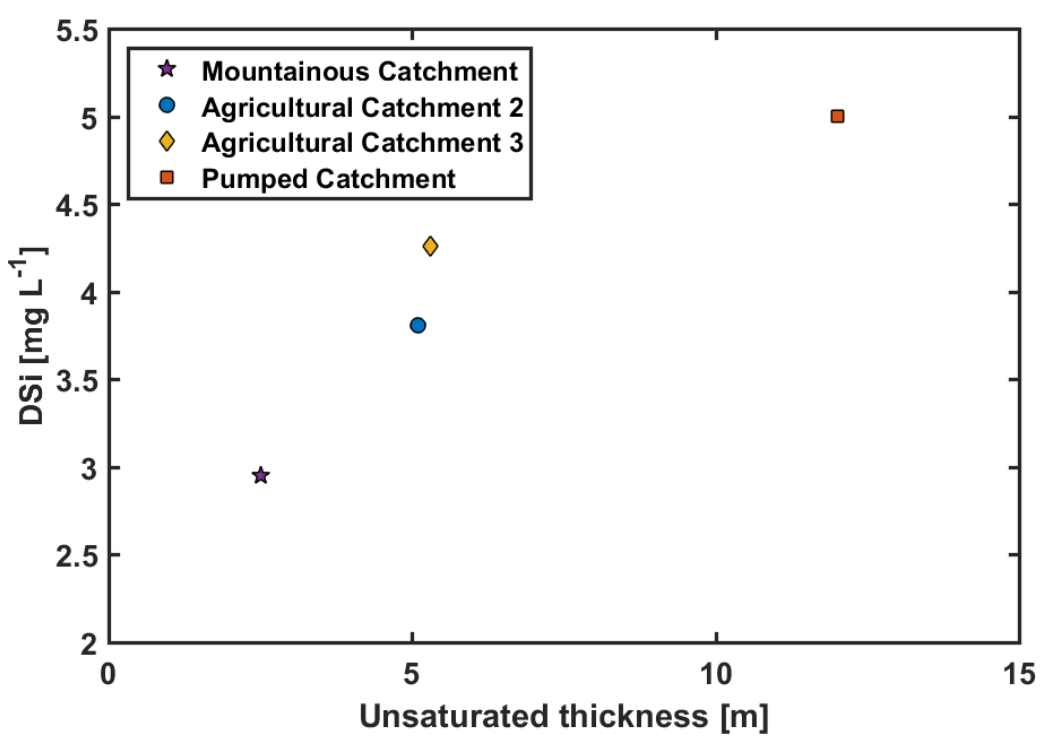

Figure 10: Initial DSi concentrations versus the average unsaturated zone thickness. The average unsaturated zone thickness of the agricultural catchment 1 was not available.

\subsection{Comparison of weathering rates to previously estimated weathering rates}

We compared the weathering rates obtained in this study with previously published studies (Table 3). The catchments considered in these studies have crystalline or sedimentary bedrocks derived from the erosion of crystalline formations. Apparent weathering rates have been estimated by different methods, either by implementing the geochemical evolution of groundwater through advanced reactive transport modeling (Burns et al., 2003; Rademacher et al., 2001) or by directly comparing DSi concentrations with apparent ages derived from atmospheric tracer data (Bohlke and Denver, 1995; Clune and Denver, 2012; Denver et al., with apparent weathering rates and inlet concentrations (atmospheric chronicles for CFCs and initial concentration $C_{S i}^{0}$ for DSi). 
Except for the data reported in Kenoyer and Bowser (1992), which consists of young

561

562

563

564

565

566

567

568

569

570

571

572

573

574

575

576

577

578

groundwater (0-4 yrs), all DSi weathering rates referred in Table 3 are within one order of magnitude (0.1 to $\left.1 \mathrm{mg} \mathrm{L}^{-1} \mathrm{yr}^{-1}\right)$. For catchments with apparent ages between 10 and 50 years, weathering rates are clustered between 0.2 and $0.4 \mathrm{mg} \mathrm{L}^{-1} \mathrm{yr}^{-1}$ (Figure 11), which is consistent with weathering rates estimated in this study.

The initial decrease of weathering rates with the typical apparent ages might suggest a power law dependence of weathering rates on groundwater age (Figure 11). However, for older apparent ages, the weathering rates might also stabilize around 20 years (Figure 11, insert) suggesting a transition from transport-limited to thermodynamically-limited conditions consistent with what has been observed for feldspar minerals (Maher, 2010) with a slightly older transition time (20 years here instead of 10 years). It will require more studies on this residence time range (0-100 yrs) to decide between these two competing hypotheses (power law dependence versus stabilization) and precisely locate the transition time (Ackerer et al., 2018). This could be investigated by systematically combining weathering studies with groundwater age tracer analysis in a diversity of environmental observatories. If predictable rates are not found, the use of a constant weathering rate (equation (1)) could be refined by considering a first order kinetic reaction, although it would require the inference of an additional parameter to describe weathering. 


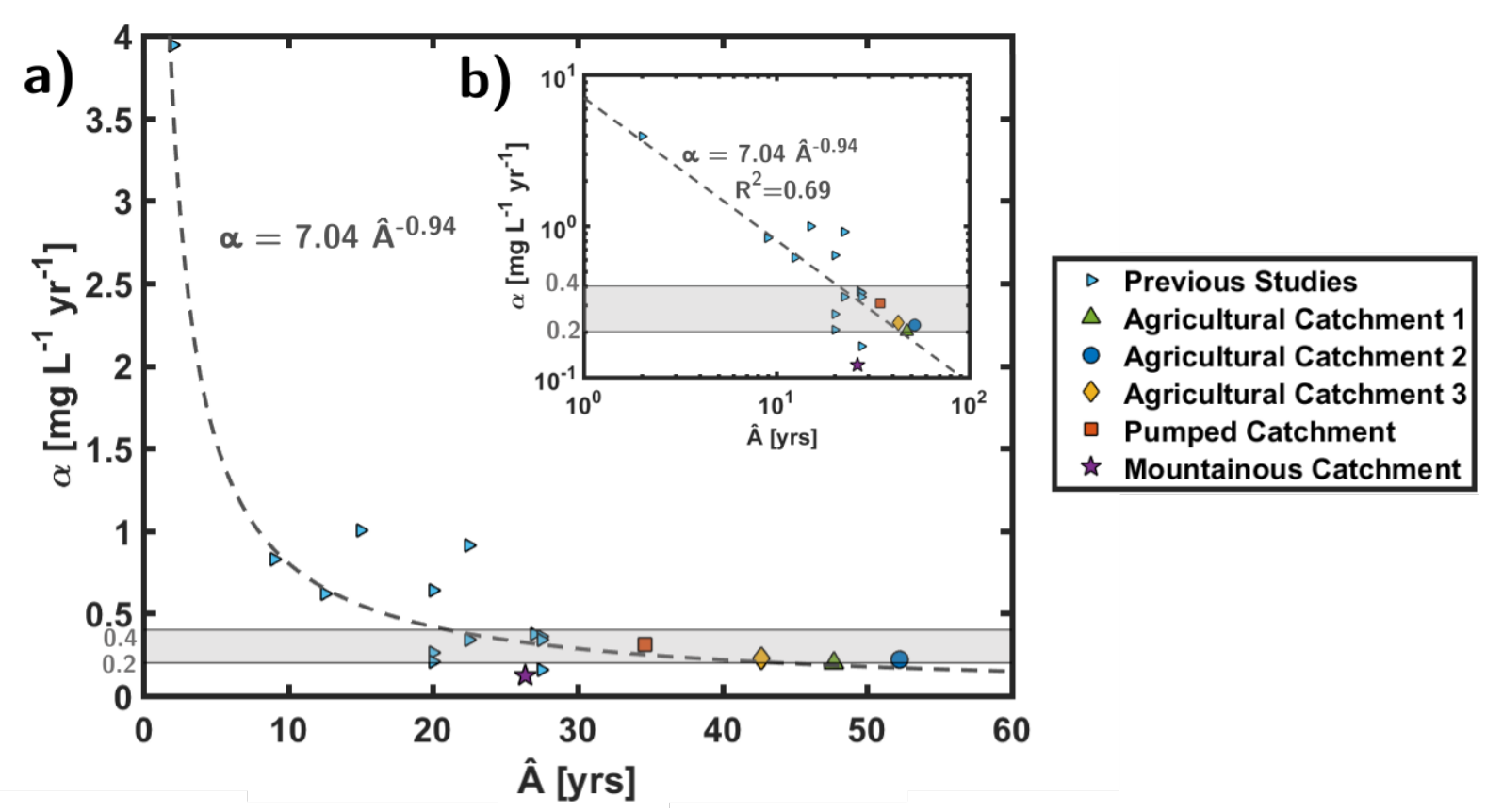

580 Figure 11: Silicate weathering rates $\alpha$ against the typical apparent age range Â from which they have been

581 obtained, in this study and in previous studies (insert: log-log representation, p-value of $210^{-5}$ obtained for 582 the fit). 


\begin{tabular}{|c|c|c|c|c|c|}
\hline Catchment & $\alpha\left[\mathrm{mg} \mathrm{L}^{-1} \mathrm{yr}^{-1}\right]$ & Geological Context & $\begin{array}{l}\text { Apparent } \\
\text { Age range }\end{array}$ & Complementary information & References \\
\hline Chesterville Branch & 0.34 & $\begin{array}{l}\text { Permeable sand and gravel units of the fluvial Pensauken Formation and } \\
\text { the marine glauconitic Aquia Formation. }\end{array}$ & $5-40 \mathrm{yrs}$ & Part of Locust Grove Catchment & (Bohlke and Denver, 1995) \\
\hline Morgan Creek Drainage & 0.37 & $\begin{array}{l}\text { Permeable sand and gravel units of the fluvial Pensauken Formation and } \\
\text { the marine glauconitic Aquia Formation. }\end{array}$ & $4-50$ yrs & Part of Locust Grove Catchment & (Bohlke and Denver, 1995) \\
\hline $\begin{array}{l}\text { Panola Mountain } \\
\text { Research Watershed }\end{array}$ & 0.62 & $\begin{array}{l}\text { Panola Granite (granodiorite composition), a biotite-oligioclase- quartz- } \\
\text { microcline granite of Mississippian to Pennsylvanian age. }\end{array}$ & $0-25$ yrs & Mainly Riparian Saprolite Aquifer & (Burns et al., 2003) \\
\hline $\begin{array}{l}\text { Bucks Branch } \\
\text { Watershed }\end{array}$ & 0.91 & Sediments of the Beaverdam Formation. & $15-30$ yrs & $\begin{array}{l}\text { mainly fluvial and estuarine deposits of } \\
\text { sand, gravel, silt, and clays }\end{array}$ & (Clune and Denver, 2012) \\
\hline Fairmount catchment & 0.26 & $\begin{array}{l}\text { Permeable quartz sand and gravel of the Beaverdam Formation and } \\
\text { underlying sandy strata of the Bethany Formation. }\end{array}$ & $5-35$ yrs & $\begin{array}{l}\text { well-drained settings with relatively deep } \\
\text { water tables and thick sandy aquifers }\end{array}$ & (Denver et al., 2010) \\
\hline $\begin{array}{l}\text { Locust Grove } \\
\text { catchment }\end{array}$ & 0.16 & $\begin{array}{l}\text { Permeable quartz sand and gravel of the Pennsauken Formation underlain } \\
\text { by highly weathered glauconitic sands of the Aquia Formation. }\end{array}$ & $5-50$ yrs & $\begin{array}{l}\text { well-drained settings with relatively deep } \\
\text { water tables and thick sandy aquifers }\end{array}$ & (Denver et al., 2010) \\
\hline Lizzie Catchment & 0.36 & $\begin{array}{l}\text { Several Pleistocene-age terrace deposits that are underlain by a confining } \\
\text { unit on the top of the Yorktown Formation. }\end{array}$ & $5-50$ yrs & $\begin{array}{l}\text { predominantly poorly drained settings with } \\
\text { shallow water tables }\end{array}$ & (Denver et al., 2010) \\
\hline Willards Catchment & 0.83 & $\begin{array}{l}\text { The lowermost unit of the system is the Beaverdam Sand, which is } \\
\text { overlain by a } 3 \text { to } 8 \mathrm{~m} \text { thick layer of clay, silt, peat, and sand of the Omar } \\
\text { Formation. }\end{array}$ & $0-18 \mathrm{yrs}$ & $\begin{array}{l}\text { predominantly poorly drained settings with } \\
\text { shallow water tables }\end{array}$ & (Denver et al., 2010) \\
\hline $\begin{array}{l}\text { Crystal Lake, Vilas } \\
\text { County (Wisconsin) }\end{array}$ & 3.94 & $50 \mathrm{~m}$ of glacial sediment which overlies Precambrian bedrock. & $0-4$ yrs & $\begin{array}{l}\text { Glacial sediments were eroded from } \\
\text { Precambrian bedrock lithologies }\end{array}$ & (Kenoyer and Bowser, 1992) \\
\hline Sagehen Springs (CA). & $0.17-1.11$ & \multirow{2}{*}{$\begin{array}{l}\text { Extensive glacial till deposits derived from a combination of andesite and } \\
\text { granodiorite basement rocks. The granodiorite consists primarily of } \\
\text { plagioclase }(40 \%) \text {, quartz ( } 30 \%) \text {, hornblende }(20 \%) \text {, and biotite }(10 \%) \text {, } \\
\text { and the andesite consists primarily of plagioclase (45\%) with varying } \\
\text { amounts of hornblende (5-25\%) and augite (1-25\%) and a small amount } \\
\text { of glassy groundmass. }\end{array}$} & $0-40$ yrs & $\begin{array}{l}\text { Range of weathering rate determined for } \\
\text { each spring, only for plagioclase mineral. }\end{array}$ & (Rademacher et al., 2001) \\
\hline Sagehen Springs (CA). & $0.06-0.35$ & & $0-40 \mathrm{yrs}$ & $\begin{array}{l}\text { Range of weathering rate determined for } \\
\text { each spring, only for hornblende mineral. }\end{array}$ & (Rademacher et al., 2001) \\
\hline Lizzie Catchment & 0.34 & $\begin{array}{l}\text { Several Pleistocene-age terrace deposits that are underlain by a confining } \\
\text { unit on the top of the Yorktown Formation. }\end{array}$ & $5-50$ yrs & Unconfined aquifer. & (Tesoriero et al., 2005) \\
\hline
\end{tabular}

584 Table 3: Published weathering rates in different catchments obtained either directly or by fitting DSi concentrations against apparent ages. The typical age range

585 gives the spread of the water age data obtained from the different sampled wells.




\section{Conclusion}

We investigated the relationship between DSi and groundwater age tracers (CFCs) in five different crystalline catchments, including lowland, mountainous, and actively pumped catchments. For each catchment, we quantified the weathering rate and the RTDs at multiple wells using inverse Gaussian lumped parameter models calibrated with geochemical data.

591 Overall, the DSi was strongly related to the exposure time between rocks and recently 592 recharged groundwater (i.e. between 5 to 100 years). We found that DSi was highly 593 complementary to CFCs, allowing better quantification of RTDs, including in the unsaturated 594 zone and for water masses younger and older than the now rapidly closing CFC use's 595 window. The consistency of DSi weathering rates in three Brittany catchments suggests that 596 DSi may be a robust and cheap groundwater age proxy at regional scales for catchments with 597 comparable geology and climate. We interpreted DSi accumulation differences in the Brittany 598 pumped site and the mountainous region, as a consequence of temperature differences and 599 alterations of flow from groundwater abstraction respectively. If the temperature sensitivity of 600 weathering can be constrained, this tracer could allow widespread determination of water 601 transit time at the catchment scale for the unsaturated zone, aquifer, and surface waters.

\section{Acknowledgements}

We acknowledge the ANR for its funding through the project Soil $\mu$-3D under the $\mathrm{n}^{\circ}$ 604 ANR-15-CE01-0006. Dataset was provided by the OZCAR Network (Ploemeur 605 hydrogeological observatory H+ network; Strengbach - Observatoire Hydrogéochimique de 606 l'Environnement) and the Zone Atelier Armorique (Pleine Fougères). We thank M. Bouhnik607 Le-Coz and V. Vergnaud for the chemical analysis. We also thank H. V. Gupta for 608 constructive discussions. 


\section{References}

Abbott BW, Baranov V, Mendoza-Lera C, Nikolakopoulou M, Harjung A, Kolbe T, et al., 2016. Using multi-tracer inference to move beyond single-catchment ecohydrology. Earth-Science Reviews. 160, 19-42. http://dx.doi.org/10.1016/j.earscirev.2016.06.014.

Abbott BW, Moatar F, Gauthier O, Fovet O, Antoine V, Ragueneau O, 2018. Trends and seasonality of river nutrients in agricultural catchments: 18years of weekly citizen science in France. Science of The Total Environment. 624, 845-858. https://doi.org/10.1016/j.scitotenv.2017.12.176.

Ackerer J, Chabaux F, Lucas Y, Clément A, Fritz B, Beaulieu E, et al., 2018. Monitoring and reactivetransport modeling of the spatial and temporal variations of the Strengbach spring hydrochemistry. Geochimica et Cosmochimica Acta. 225, 17-35. https://doi.org/10.1016/j.gca.2018.01.025.

Anderson RS, Anderson SP, 2010. Geomorphology: the mechanics and chemistry of landscapes: Cambridge University Press.

Anderson SP, Dietrich WE, Brimhall GH, 2002. Weathering profiles, mass-balance analysis, and rates of solute loss: Linkages between weathering and erosion in a small, steep catchment. Geological Society of America Bulletin. 114, 1143-1158.

Appelo C, Postma D, 1994. Geochemistry, Groundwater and Pollution: AA Balkema, Brookfield.

Aquilina L, Poszwa A, Walter C, Vergnaud V, Pierson-Wickmann A-C, Ruiz L, 2012a. Long-Term Effects of High Nitrogen Loads on Cation and Carbon Riverine Export in Agricultural Catchments. Environmental Science \& Technology. 46, 9447-9455. 10.1021/es301715t.

Aquilina L, Vergnaud-Ayraud V, Labasque T, Bour O, Molenat J, Ruiz L, et al., 2012b. Nitrate dynamics in agricultural catchments deduced from groundwater dating and long-term nitrate monitoring in surface- and groundwaters. Science of the Total Environment. 435, 167-178. 10.1016/j.scitotenv.2012.06.028.

Aubert D, Stille P, Probst A, 2001. REE fractionation during granite weathering and removal by waters and suspended loads: $\mathrm{Sr}$ and Nd isotopic evidence. Geochimica et Cosmochimica Acta. 65, 387-406. http://dx.doi.org/10.1016/S0016-7037(00)00546-9.

Ayraud V, 2005. Détermination du temps de résidence des eaux souterraines: application au transfert d'azote dans les aquifères fracturés hétérogènes. Université Rennes 1

Ayraud V, Aquilina L, Labasque T, Pauwels H, Molenat J, Pierson-Wickmann A-C, et al., 2008. Compartmentalization of physical and chemical properties in hard-rock aquifers deduced from chemical and groundwater age analyses. Applied Geochemistry. 23, 2686-2707. https://doi.org/10.1016/j.apgeochem.2008.06.001.

Becker SK, 2013. Assessing the Use of Dissolved Silicon as a Proxy for Groundwater Age: A Critical Analysis of Published Data and New Data from the North Carolina Coastal Plain. MSc

Beyer M, Jackson B, Daughney C, Morgenstern U, Norton K, 2016. Use of hydrochemistry as a standalone and complementary groundwater age tracer. Journal of Hydrology. 543, 127-144. 10.1016/j.jhydrol.2016.05.062.

Bochet O, 2017. Caractérisation des hot spots de réactivité biogéochimique dans les eaux souterraines. Rennes 1

Bochet O, Bethencourt L, Dufresne A, Pedrot M, Farasin J, Labasque T, et al., under revision. Dynamic microbiological hot spots sustained by mixing in subsurface fractures. Nature Geosci. 
Bohlke JK, Denver JM, 1995. Combined use of groundwater dating, chemical, and isotopic analyses to resolve the history and fate of nitrate contamination in 2 agricultural watersheds, atlantic coastal-plain, maryland. Water Resources Research. 31, 2319-2339. 10.1029/95wr01584.

Bouhnik-Le Coz M, Petitjean P, Serrat E, Gruau G, 2001. Validation d'un protocole permettant le dosage simultané des cations majeurs et traces dans les eaux douces naturelles par ICP-MS

Bouraoui F, Grizzetti B, 2011. Long term change of nutrient concentrations of rivers discharging in European seas. Science of The Total Environment. 409, 4899-4916. http://dx.doi.org/10.1016/j.scitotenv.2011.08.015.

Burns DA, Plummer LN, McDonnell JJ, Busenberg E, Casile GC, Kendall C, et al., 2003. The Geochemical Evolution of Riparian Ground Water in a Forested Piedmont Catchment. Ground Water. 41, 913-925. 10.1111/j.1745-6584.2003.tb02434.x.

Busenberg E, Plummer LN, 1992. Use of chlorofluorocarbons (CCl3F and CCl2F2) as hydrologic tracers and age-dating tools: The alluvium and terrace system of central Oklahoma. Water Resources Research. 28, 2257-2283. 10.1029/92WR01263.

Chabaux F, Viville D, Lucas Y, Ackerer J, Ranchoux C, Bosia C, et al., 2017. Geochemical tracing and modeling of surface and deep water-rock interactions in elementary granitic watersheds (Strengbach and Ringelbach CZOs, France). Acta Geochimica. 36, 363-366. 10.1007/s11631017-0163-5.

Clune JW, Denver JM, 2012. Residence Time, Chemical and Isotopic Analysis of Nitrate in the Groundwater and Surface Water of a Small Agricultural Watershed in the Coastal Plain, Bucks Branch, Sussex County, Delaware: US Department of the Interior, US Geological Survey.

Cook PG, Herczeg AL, 2000. Environmental Tracers in Subsurface Hydrology: Springer.

De Dreuzy J-R, Bodin J, Le Grand H, Davy P, Boulanger D, Battais A, et al., 2006. General Database for Ground Water Site Information. Ground Water. 44, 743-748. 10.1111/j.17456584.2006.00220.x.

Delvaux C, Cardinal D, Carbonnel V, Chou L, Hughes HJ, André L, 2013. Controls on riverine $\delta 30 \mathrm{Si}$ signatures in a temperate watershed under high anthropogenic pressure (Scheldt - Belgium). Journal of Marine Systems. 128, 40-51. https://doi.org/10.1016/j.jmarsys.2013.01.004.

Denver JM, Tesoriero AJ, Barbaro JR, 2010. Trends and Transformation of Nutrients and Pesticides in a Coastal Plain Aquifer System, United States All rights reserved. No part of this periodical may be reproduced or transmitted in any form or by any means, electronic or mechanical, including photocopying, recording, or any information storage and retrieval system, without permission in writing from the publisher. Journal of Environmental Quality. 39, 154-167. 10.2134/jeq2009.0107.

Eberts SM, Bohlke JK, Kauffman LJ, Jurgens BC, 2012. Comparison of particle-tracking and lumpedparameter age-distribution models for evaluating vulnerability of production wells to contamination. Hydrogeology Journal. 20, 263-282. 10.1007/s10040-011-0810-6.

Edmunds WM, Smedley PL, 2000. Residence time indicators in groundwater: the East Midlands Triassic sandstone aquifer. Applied Geochemistry. 15, 737-752. http://dx.doi.org/10.1016/S0883-2927(99)00079-7.

Galloway JN, Townsend AR, Erisman JW, Bekunda M, Cai Z, Freney JR, et al., 2008. Transformation of the Nitrogen Cycle: Recent Trends, Questions, and Potential Solutions. Science. 320, 889892. 10.1126/science.1136674.

Gelhar LW, Axness CL, 1983. Three-dimensional stochastic analysis of macrodispersion in aquifers. Water Resources Research. 19, 161-180. 
699

700

701

702

703

704

705

706

707

708

709

710

711

712

713

714

715

716

717

718

719

720

721

722

723

724

725

726

727

728

729

730

731

732

733

734

735

736

737

738

739

740

741

742

743

Green CT, Zhang Y, Jurgens BC, Starn JJ, Landon MK, 2014. Accuracy of travel time distribution (TTD) models as affected by TTD complexity, observation errors, and model and tracer selection. Water Resources Research, 6191 - 6213. 10.1002/2014WR015625.

Haggerty R, Gorelick SM, 1995. Multiple-rate mass transfer for modeling diffusion and surface reactions in media with pore-scale heterogeneity. Water Resources Research. 31, 2383-2400. 10.1029/95WR10583.

Haitjema HM, 1995. Analytic element modeling of groundwater flow: Academic press.

Hughes HJ, Sondag F, Santos RV, André L, Cardinal D, 2013. The riverine silicon isotope composition of the Amazon Basin. Geochimica et Cosmochimica Acta. 121, 637-651. https://doi.org/10.1016/j.gca.2013.07.040.

Iler RK, 1979. The chemistry of silica: solubility, polymerization, colloid and surface properties, and biochemistry. . Canada: John Wiley \&Sons Inc

Ingber L, 2000. Adaptive simulated annealing (ASA): Lessons learned. eprint arXiv:cs/0001018

Jarvie HP, Sharpley, A.N., Withers, P.J.A., Scott, J.T., Haggard, B.E., Neal, C., 2013. Phosphorus Mitigation to Control River Eutrophication: Murky Waters, Inconvenient Truths, and “Postnormal” Science. J. Environ. Qual. . 42, 295-304. 10.2134/jeq2012.0085.

Jasechko S, Perrone D, Befus KM, Bayani Cardenas M, Ferguson G, Gleeson T, et al., 2017. Global aquifers dominated by fossil groundwaters but wells vulnerable to modern contamination. Nature Geosci. 10, 425-429. 10.1038/ngeo2943.

Jenny J-P, Normandeau A, Francus P, Taranu ZE, Gregory-Eaves I, Lapointe F, et al., 2016. Urban point sources of nutrients were the leading cause for the historical spread of hypoxia across European lakes. Proceedings of the National Academy of Sciences. 113, 12655-12660. 10.1073/pnas.1605480113.

Jiménez-Martínez J, Longuevergne L, Le Borgne T, Davy P, Russian A, Bour O, 2013. Temporal and spatial scaling of hydraulic response to recharge in fractured aquifers: Insights from a frequency domain analysis. Water Resources Research. 49, 3007-3023. 10.1002/wrcr.20260.

Jurgens BC, Böhlke JK, Eberts SM, 2012. TracerLPM (Version 1): An Excel ${ }^{\circledR}$ workbook for interpreting groundwater age distributions from environmental tracer data. U.S. Geological Survey Techniques and Methods Report, 60.

Kenoyer GJ, Bowser CJ, 1992. Groundwater chemical evolution in a sandy silicate aquifer in northern Wisconsin: 1. Patterns and rates of change. Water Resources Research. 28, 579-589. 10.1029/91WR02302.

Kim K, 2002. Plagioclase weathering in the groundwater system of a sandy, silicate aquifer. Hydrological Processes. 16, 1793-1806. doi:10.1002/hyp.1081.

Kolbe T, Marçais J, Thomas Z, Abbott BW, de Dreuzy J-R, Rousseau-Gueutin P, et al., 2016. Coupling 3D groundwater modeling with CFC-based age dating to classify local groundwater circulation in an unconfined crystalline aquifer. Journal of Hydrologyhttp://dx.doi.org/10.1016/j.jhydrol.2016.05.020.

Labasque T, Aquilina L, Vergnaud V, Barbecot F, 2014. Inter-laboratory comparison of the analyses of sulphur hexafluoride (SF6) and three chlorofluorocarbons (CFC-11, -12 and -113) in groundwater and an air standard. Applied Geochemistry. 50, 118-129. http://dx.doi.org/10.1016/j.apgeochem.2014.03.009.

Labasque T, Ayraud V, Aquilina L, Le Corre P, 2006. Dosage des composés chlorofluorocarbonés et du tétrachlorure de carbone dans les eaux souterraines: application à la datation des eaux. Cahiers Techniques de Géosciences Rennes. 4 
Le Borgne T, Bour O, Paillet FL, Caudal JP, 2006. Assessment of preferential flow path connectivity and hydraulic properties at single-borehole and cross-borehole scales in a fractured aquifer. Journal of Hydrology. 328, 347-359.

Legout C, Molenat J, Aquilina L, Gascuel-Odoux C, Faucheux M, Fauvel Y, et al., 2007. Solute transfer in the unsaturated zone-groundwater continuum of a headwater catchment. Journal of Hydrology. 332, 427-441. http://dx.doi.org/10.1016/j.jhydrol.2006.07.017.

Legout C, Molenat J, Lefebvre S, Marmonier P, Aquilina L, 2005. Investigation of biogeochemical activities in the soil and unsaturated zone of weathered granite. Biogeochemistry. 75, 329-350. 10.1007/s10533-005-0110-0.

Leray S, de Dreuzy J-R, Bour O, Aquilina L, Labasque T, 2012. Contribution of age data to the characterization of complex aquifers. Journal of Hydrology, 54-68.

Leray S, Engdahl NB, Massoudieh A, Bresciani E, McCallum J, 2016. Residence time distributions for hydrologic systems: Mechanistic foundations and steady-state analytical solutions. Journal of Hydrologyhttp://dx.doi.org/10.1016/j.jhydrol.2016.01.068.

Lindsey BD, Phillips SW, Donnelly CA, Speiran GK, Plummer LN, Böhlke J-K, et al., 2003. Residence times and nitrate transport in ground water discharging to streams in the Chesapeake Bay Watershed. US Geological Survey Water-Resources Investigations Report. 3, 4035.

Lucas Y, Chabaux F, Schaffhauser T, Fritz B, Ambroise B, Ackerer J, et al., 2017. Hydrogeochemical modeling (KIRMAT) of spring and deep borehole water compositions in the small granitic Ringelbach catchment (Vosges Mountains, France). Applied Geochemistry. 87, 1-21. https://doi.org/10.1016/j.apgeochem.2017.10.005.

Maher K, 2010. The dependence of chemical weathering rates on fluid residence time. Earth and Planetary Science Letters. 294, 101-110. http://dx.doi.org/10.1016/j.epsl.2010.03.010.

Maher K, 2011. The role of fluid residence time and topographic scales in determining chemical fluxes from landscapes. Earth and Planetary Science Letters. 312, 48-58. http://dx.doi.org/10.1016/j.epsl.2011.09.040.

Maher K, Druhan J, 2014. Relationships between the Transit Time of Water and the Fluxes of Weathered Elements through the Critical Zone. Procedia Earth and Planetary Science. 10, 1622. https://doi.org/10.1016/j.proeps.2014.08.004.

Maloszewski P, Zuber A, 1996. Lumped parameter models for the interpretation of environmentaltracer data. In: Manual On Mathematical Models in Isotope Hydrology. Vienna, Austria, IAEA-TECDOC. 910, 9-58.

Marçais J, de Dreuzy JR, Ginn TR, Rousseau-Gueutin P, Leray S, 2015. Inferring transit time distributions from atmospheric tracer data: Assessment of the predictive capacities of Lumped Parameter Models on a 3D crystalline aquifer model. Journal of Hydrology. 525, 619-631. http://dx.doi.org/10.1016/j.jhydrol.2015.03.055.

Meter KJV, Basu NB, 2017. Time lags in watershed-scale nutrient transport: an exploration of dominant controls. Environmental Research Letters. 12, 084017. https://doi.org/10.1088/17489326/aa7bf4.

Meter KJV, Basu NB, Veenstra JJ, Burras CL, 2016. The nitrogen legacy: emerging evidence of nitrogen accumulation in anthropogenic landscapes. Environmental Research Letters. 11, 035014. https://doi.org/10.1088/1748-9326/11/3/035014.

Morgenstern U, Daughney CJ, Leonard G, Gordon D, Donath FM, Reeves R, 2015. Using groundwater age and hydrochemistry to understand sources and dynamics of nutrient contamination through the catchment into Lake Rotorua, New Zealand. Hydrology and Earth System Sciences. 19, 803-822. 10.5194/hess-19-803-2015. 
Morgenstern U, Stewart MK, Stenger R, 2010. Dating of streamwater using tritium in a post nuclear bomb pulse world: continuous variation of mean transit time with streamflow. Hydrol. Earth Syst. Sci. 14, 2289-2301. 10.5194/hess-14-2289-2010.

Peters NE, Burns DA, Aulenbach BT, 2014. Evaluation of High-Frequency Mean Streamwater Transit-Time Estimates Using Groundwater Age and Dissolved Silica Concentrations in a Small Forested Watershed. Aquatic Geochemistry. 20, 183-202. 10.1007/s10498-013-9207-6.

Pfister L, Wetzel CE, Klaus J, Martínez-Carreras N, Antonelli M, Teuling AJ, et al., 2017. Terrestrial diatoms as tracers in catchment hydrology: a review. Wiley Interdisciplinary Reviews: Water. 4, e1241. doi:10.1002/wat2.1241.

Pierret MC, Stille P, Prunier J, Viville D, Chabaux F, 2014. Chemical and U-Sr isotopic variations in stream and source waters of the Strengbach watershed (Vosges mountains, France). Hydrol. Earth Syst. Sci. 18, 3969-3985. 10.5194/hess-18-3969-2014.

Pinay G, Peiffer S, De Dreuzy J-R, Krause S, Hannah D, Fleckenstein J, et al., 2015. Upscaling Nitrogen Removal Capacity from Local Hotspots to Low Stream Orders’ Drainage Basins. Ecosystems, 1-20. 10.1007/s10021-015-9878-5.

Rademacher LK, Clark JF, Hudson GB, Erman DC, Erman NA, 2001. Chemical evolution of shallow groundwater as recorded by springs, Sagehen basin; Nevada County, California. Chemical Geology. 179, 37-51. https://doi.org/10.1016/S0009-2541(01)00314-X.

Rockstrom J, Steffen W, Noone K, Persson A, Chapin FS, III, Lambin EF, et al., 2009. A safe operating space for humanity. Nature. 461, 472-475. 10.1038/461472a.

Roques C, Aquilina L, Bour O, Maréchal J-C, Dewandel B, Pauwels H, et al., 2014a. Groundwater sources and geochemical processes in a crystalline fault aquifer. Journal of Hydrology. 519, Part D, 3110-3128. http://dx.doi.org/10.1016/j.jhydrol.2014.10.052.

Roques C, Bour O, Aquilina L, Dewandel B, Leray S, Schroetter JM, et al., 2014b. Hydrological behavior of a deep sub-vertical fault in crystalline basement and relationships with surrounding reservoirs. Journal of Hydrology. 509, 42-54. http://dx.doi.org/10.1016/j.jhydrol.2013.11.023.

Sebilo M, Mayer B, Nicolardot B, Pinay G, Mariotti A, 2013. Long-term fate of nitrate fertilizer in agricultural soils. Proceedings of the National Academy of Sciences of the United States of America. 110, 18185-18189. 10.1073/pnas.1305372110.

Singleton MJ, Esser BK, Moran JE, Hudson GB, McNab WW, Harter T, 2007. Saturated Zone Denitrification: Potential for Natural Attenuation of Nitrate Contamination in Shallow Groundwater Under Dairy Operations. Environmental Science \& Technology. 41, 759-765. 10.1021/es061253g.

Spalding RF, Exner ME, 1993. Occurrence of nitrate in groundwater - a review. Journal of Environmental Quality. 22, 392-402. 10.2134/jeq1993.00472425002200030002x.

Steffen W, Richardson K, Rockström J, Cornell SE, Fetzer I, Bennett EM, et al., 2015. Planetary boundaries: Guiding human development on a changing planet. Science. 34710.1126/science.1259855.

Stewart MK, Mehlhorn J, Elliott S, 2007. Hydrometric and natural tracer (oxygen-18, silica, tritium and sulphur hexafluoride) evidence for a dominant groundwater contribution to Pukemanga Stream, New Zealand. Hydrological Processes. 21, 3340-3356. doi:10.1002/hyp.6557.

Suckow A, 2014. The age of groundwater - Definitions, models and why we do not need this term. Applied Geochemistry. 50, 222-230. 10.1016/j.apgeochem.2014.04.016.

Tarits C, Aquilina L, Ayraud V, Pauwels H, Davy P, Touchard F, et al., 2006. Oxido-reduction sequence related to flux variations of groundwater from a fractured basement aquifer 
(Ploemeur area, France). Applied Geochemistry. 21, 29-47. https://doi.org/10.1016/j.apgeochem.2005.09.004.

Tesoriero AJ, Spruill TB, Mew HE, Farrell KM, Harden SL, 2005. Nitrogen transport and transformations in a coastal plain watershed: Influence of geomorphology on flow paths and residence times. Water Resources Research. 41, n/a-n/a. 10.1029/2003WR002953.

Thamatrakoln K, Hildebrand M, 2008. Silicon uptake in diatoms revisited: a model for saturable and nonsaturable uptake kinetics and the role of silicon transporters. Plant Physiol. 146, 1397-407. 10.1104/pp.107.107094.

Thomas Z, Abbott BW, Troccaz O, Baudry J, Pinay G, 2016a. Proximate and ultimate controls on carbon and nutrient dynamics of small agricultural catchments. Biogeosciences. 13, 18631875. 10.5194/bg-13-1863-2016.

Thomas Z, Rousseau-Gueutin P, Kolbe T, Abbott BW, Marçais J, Peiffer S, et al., 2016b. Constitution of a catchment virtual observatory for sharing flow and transport models outputs. Journal of Hydrology. 543, 59-66. https://doi.org/10.1016/j.jhydrol.2016.04.067.

Touchard F, 1999. Caractérisation hydrogéologique d'un aquifère en socle fracturé. Site de Ploëmeur (Morbihan).

Visser A, Broers HP, Purtschert R, Sultenfuss J, de Jonge M, 2013. Groundwater age distributions at a public drinking water supply well field derived from multiple age tracers (Kr-85, H-3/He-3, and Ar-39). Water Resources Research. 49, 7778-7796. 10.1002/2013wr014012.

Visser A, Fourré E, Barbecot F, Aquilina L, Labasque T, Vergnaud V, et al., 2014. Intercomparison of tritium and noble gases analyses, 3H/3He ages and derived parameters excess air and recharge temperature. $\quad$ Applied $\quad$ Geochemistry. $\quad$ 50, 130-141. http://dx.doi.org/10.1016/j.apgeochem.2014.03.005.

Viville D, Chabaux F, Stille P, Pierret MC, Gangloff S, 2012. Erosion and weathering fluxes in granitic basins: The example of the Strengbach catchment (Vosges massif, eastern France). CATENA. 92, 122-129. http://dx.doi.org/10.1016/j.catena.2011.12.007.

White AF, 2008. Quantitative Approaches to Characterizing Natural Chemical Weathering Rates. In: Brantley SL, Kubicki JD, White AF, editors. Kinetics of Water-Rock Interaction. Springer New York, New York, NY, pp. 469-543.

White AF, Blum AE, 1995. Effects of climate on chemical weathering in watersheds. Geochimica et Cosmochimica Acta. 59, 1729-1747. http://dx.doi.org/10.1016/0016-7037(95)00078-E.

White AF, Blum AE, Bullen TD, Vivit DV, Schulz M, Fitzpatrick J, 1999. The effect of temperature on experimental and natural chemical weathering rates of granitoid rocks. Geochimica et Cosmochimica Acta. 63, 3277-3291. http://dx.doi.org/10.1016/S0016-7037(99)00250-1.

White AF, Brantley SL, 2003. The effect of time on the weathering of silicate minerals: why do weathering rates differ in the laboratory and field? Chemical Geology. 202, 479-506. http://dx.doi.org/10.1016/j.chemgeo.2003.03.001.

White AF, Bullen TD, Schulz MS, Blum AE, Huntington TG, Peters NE, 2001. Differential rates of feldspar weathering in granitic regoliths. Geochimica et Cosmochimica Acta. 65, 847-869. http://dx.doi.org/10.1016/S0016-7037(00)00577-9.

Wilcock RJ, Monaghan RM, Quinn JM, Srinivasan MS, Houlbrooke DJ, Duncan MJ, et al., 2013. Trends in water quality of five dairy farming streams in response to adoption of best practice and benefits of long-term monitoring at the catchment scale. Marine and Freshwater Research. 64, 401-412. https://doi.org/10.1071/MF12155. 